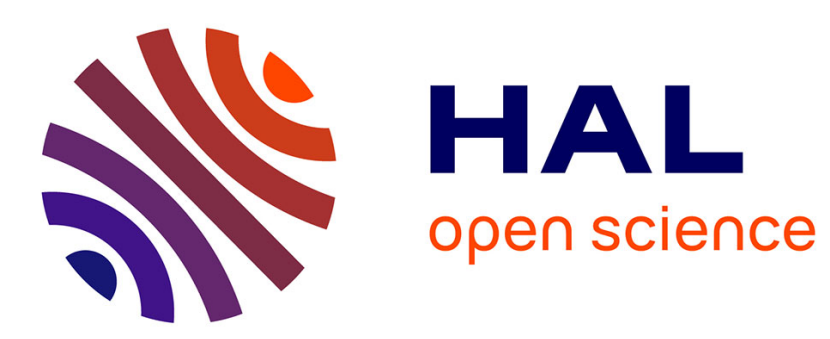

\title{
Emerging Countries Sovereign Rating Adjustment using Market Information: Impact on Financial Institutions Investment Decisions
}

Dominique Guegan, Bertrand Hassani, Xin Zhao

\section{- To cite this version:}

Dominique Guegan, Bertrand Hassani, Xin Zhao. Emerging Countries Sovereign Rating Adjustment using Market Information: Impact on Financial Institutions Investment Decisions. 2013. halshs00820839

\section{HAL Id: halshs-00820839 \\ https://shs.hal.science/halshs-00820839}

Submitted on 6 May 2013

HAL is a multi-disciplinary open access archive for the deposit and dissemination of scientific research documents, whether they are published or not. The documents may come from teaching and research institutions in France or abroad, or from public or private research centers.
L'archive ouverte pluridisciplinaire HAL, est destinée au dépôt et à la diffusion de documents scientifiques de niveau recherche, publiés ou non, émanant des établissements d'enseignement et de recherche français ou étrangers, des laboratoires publics ou privés. 


\section{Documents de Travail du Centre d'Economie de la Sorbonne}

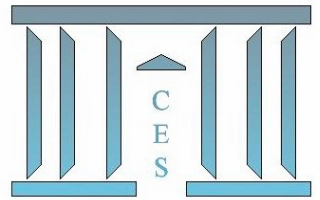

Emerging Countries Sovereign Rating Adjustment using

Market Information: Impact on Financial Institutions Investment Decisions

Dominique GuEGAN, Bertrand K. HASSANI, Xin ZHAO

2013.34

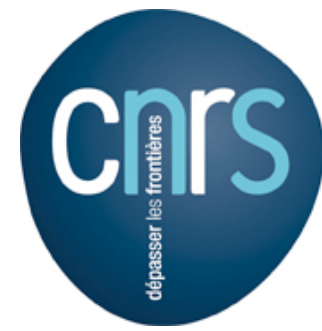




\title{
Emerging Countries Sovereign Rating Adjustment using Market Information: Impact on Financial Institutions Investment Decisions
}

\author{
March 27, 2013
}

\section{Authors:}

\section{Dominique Guégan:}

Université Paris 1 Panthéon-Sorbonne CES UMR 8174; Address: 106 Boulevard de l'Hôpital 75647 Paris Cedex 13, France; Phone: +33144078298; E-mail: dguegan@univ-paris1.fr

\section{Bertrand K. Hassani:}

Santander UK, Université Paris 1 Panthéon-Sorbonne CES UMR 8174; Address: 3 Triton Square, NW1 3AN London, United Kingdom; Phone: +44(0)7530167299; E-mail: bertrand.hassani@santander.co.uk

\section{Xin Zhao:}

Université Paris 1 Panthéon-Sorbonne, CES UMR 8174; Address: 106 Boulevard de l'Hôpital 75647 Paris Cedex 13, France; Phone: +33(0)646895934; E-mail: xinzhao0617@gmail.com 


\begin{abstract}
Assets, debts and other financial products issued by emerging countries are usually considered more speculative than those issued by developed economies. Therefore, relying on traditional rating agencies to invest in these countries is problematic as the information used to assess the economic and market condition in these economies is quickly outdated. Consequently, both the investment opportunities and the necessity to clear particular positions may be missed, respectively resulting in potential significant costs of opportunity or losses. Therefore, an approach taking into account the latest information displayed by financial markets may enable us bypassing the traditional limits. As a result, this chapter proposes a creditworthiness evaluation methodology based on adjusting ratings obtained from macroeconomic fundamentals (GDP growth rate, inflation, external debts, etc.) and financial market movements (bonds, equity volume, volatility, etc.). In the first step, a general panel model is applied on country-specific information to generate fundamental ratings. In the second step, applying a multi-factor model to market indicators and breaking down long-term sovereign bond yields into different risk premia, market implied ratings are obtained. Finally, the rating to be considered (denoted " $\delta$-Rating") for investment purposes is a combination of fundamental ratings and market implied ratings carrying out an adapted Bühlmann-Straub method (Credibility Theory). Then, emerging countries " $\delta$-Rating" will be compared to those obtained from developed countries and discussed against financial institutions risk appetite.
\end{abstract}

Key words: Credit Risk, Rating, Panel Model, Multi-factor regression, Credibility Theory 


\section{Introduction}

The term of emerging markets or emerging economies refers to the nations with social or business activity in the process of rapid growth and industrialization. Within these class of economies, it is possible to differentiate different families, as for sure Morroco and China do not have the same profile despite the fact that they are both emerging countries. The seven largest emerging economies according to nominal gross domestic product (GDP) are Brazil, Russia, India, China (the BRICs), Mexico, Indonesia, and Turkey. S\&P/IFC index ${ }^{1}$ considers a market to be emerging if it satisfies at least one of the criteria:

1. It is in a low- or middle- income country, as defined by the World Bank, and

2. Its investable market capitalization is low relative to its most recent GDP figures.

In contrast, $\mathrm{S} \& \mathrm{P} / \mathrm{IFC}$ defines a market as developed if it is in a country where gross national product (GNP) per capita exceeds the World Bank upper income threshold for at least three consecutive years and the investable market capitalization-to-GDP ratio is in the top $25 \%$ of the emerging market universe for more than three consecutive years.

Regarding the risks for investor, emerging markets are usually considered relatively riskier than developed countries as they carry additional political, economical and currency risks. Investing in emerging markets may lead to volatile returns, i.e. the probabilities of both large profits and large losses are high. The upside of investing in emerging markets is that their performance is considered usually less correlated with developed markets. As a result, these may be good investments for diversification purposes. Consequently, nowadays developing countries are major investments targets, and these fast growing economies are usually a growth relay for major banks. The second criterion highlights the fact that these economies are growing so fast that the information characterizing them is rapidly outdated as their structure is quickly evolving. Therefore, relying on the traditional rating agencies (e.g. Fitch, Moody's and S\&P's) to evaluate the risk of investing in these economies may be misleading, especially when the investment horizon is short or medium term. Indeed, by not integrating the latest information contained in the market, they may not provide the freshest point of views. It is important recalling that the rating is suppose to reflect the credit worthiness of a country, i.e. its probability of default. The consideration of fast growing economies allows us assuming that the related quickly growing cash flows generated decrease the probability of default of these country on a constant basis.

Although there are papers doubting the quality of evaluations provided by rating agencies, investors keep relying them. The problems of their evaluations have been largely unveiled during the East Asian Crisis and the recent European Sovereign Debt Crisis. Regulators and market practitioners have acknowledged the problems caused by external analysis, and as a consequence financial institutions developed internal rating methodologies $2^{2}$ External ratings, however, are still used as benchmark or important input of inside rating models. Possible explanations are that ratings provided by the major agencies are widely spread, easy to understand, and as a result contribute to limit information bias. Moreover, discussions concerning the problems of rating system and propositions of new rating methods in recent literature have not reached any consensus. There are two school of thoughts: the first states that the credit of a country is determined by its fundamental economic condition, therefore, ratings should rely on country-specific fundamentals; the second argues that economic fundamentals are insufficient to model sovereign credit risk and they propose to use market information.

In order to construct a rating methodology, the causal factors of sovereign default need to be analyzed, and these are different from the determinants of corporate defaults (Duffie et al.(2003) 9 ). The risk of investing in a country is linked to its economic condition. Therefore, it is natural to start analyzing the credit quality of a country using its fundamental indicators. Literatures discussing relationship between country fundamentals and ratings include Cantor and Packer(1996) 6], Ferri et al.(1999) [12], Mellios and

\footnotetext{
${ }^{1} \mathrm{~S} \& \mathrm{P}$ using data acquired from International Finance Corporation, produces a number of capitalization weighted indexes to measure emerging securities market including: S\&P/IFCG (Global) Indexes and S\&P/IFCI (Investable) Indexes

${ }^{2}$ Basel II/III: banks meeting certain conditions are allowed to use internal risk parameters calculating regulatory capital.
} 
Paget-Blanc(2006) 19], and many others. Cantor and Packer(1996)[6] have shown that Moody's and S\&P's ratings can be explained by a number of well-defined economic criteria. Ferri et al.(1999) [12] used these indicators to compare the ratings pre- and post- East Asian crisis. They reached the conclusion that rating agencies failed predicting the emergence of the East Asian crisis and attributed worse ratings than what the countries' fundamental economic condition deserved. They also argued that this undervaluation amplified the East Asian crisis. To solve the problems engendered by the previous approach, Mellios and Paget-Blanc(2006) 19] suggested to add other indicators, through which they emphasized the importance of political variables. However, the second school of thoughts claims that sovereign risk cannot be fully explained by country-specific fundamentals, especially for the risk in emerging market, as market opinions may influence the perception of a country credit quality up to a certain extent. This argument partially explains the inertia of agencies' rating. It is generally accepted that markets react faster than agencies to evaluate the credit worthiness of sovereigns. Hettenhouse and Sartoris(1976) 15 and Weinstein(1977) 23 . have shown that bond prices are systematically reacting to the signals implying a credit quality variation before agencies modify the ratings. Ederington et al.(1984) 10. stated that market practitioners evaluate issuer's creditworthiness according to their expectations and the market risk perception, and these are not considered by rating agencies. To capture market's attitude towards sovereign risk, Cunningham et al.(2001) 8 discussed the relationship between government bonds yield spreads and the corresponding default risks on emerging market, where they claimed that information contained in yield spreads are multi-faceted. They mentioned the importance of investors' appetite for risk evaluation and the value of liquidity for specific instruments. Perraudin and Taylor(2004) 22 have shown that sovereign bond valuations are inconsistent with their ratings. They claimed that the inconsistency can be eliminated by adjusting the prices for the effects of taxes, liquidity and other risk premiums. They also proved the inconsistencies between ratings and spreads are naturally eliminated over time. Mainstream discussions concerning market evaluated sovereign risk focus on detecting determinants of risk proxy from market, such as bond yields and credit default swaps. Baek et al.(2005) [2] claimed that risk appetite can explain the movement of bond yields. They further proved that investors' risk attitude was not considered in public ratings. Longstaff et al.(2011) 18] decomposed credit spreads into several risk premiums. They found that sovereign credit risk was more driven by market factors, risk premiums and investment flows than by country-specific fundamentals. Moreover, they found strong relationship between credit spreads and VIX index. In summary, movements of market indicators are closely related to agencies' ratings, but ratings issued by agencies are not consistent with investors' perceptions as fundamental indicators cannot fully explain the part of sovereign risk nested in market sentiments.

Therefore, this chapter presents a methodology to combine information obtained from macroeconomic indicator (fundamental rating) on the first hand and financial market (market implied rating) on the other hand in order to construct a rating reflecting both the targeted state's economic health and the global market evaluation of the sovereign's creditworthiness. This approach is referred as the $\delta$-rating approach in the following. By means of this hybrid approach, it is possible to offer more timeless ratings compared to agencies' valuations and provide prompt signals for investment opportunities or necessity to sell. Therefore, this approach enables improving the investment strategy in emerging countries as being a more reality and reactive methodology comparing to the traditional approach.

To create the $\delta$-ratings, three steps are required. In a first step, country-specific fundamental information is modeled using a general panel model to obtain a basic long-term country-specific implied rating. In a second step, a multi-factor model is applied to decompose bond yields into different risk premiums. Then, market implied ratings are computed from the stripped credit risk premium. In a final step, the $\delta$-rating is evaluated applying a simplified version of the Bühlmann-Straub credibility theory (Bühlmann and Alois (2005)[5]) which may be summarized by the following formula:

$$
\delta \text {-Rating }=\omega \cdot \text { Fundamental Rating }+(1-\omega) \cdot \text { Market Implied Rating, }
$$

where, $\omega$ is the credibility weight calculated by Bühlmann-Straub method. 
This chapter proposes a method which systematically matches low-frequency macroeconomic data with high-frequency financial market data in the modeling of sovereign rating, it analyzes how market demands and risk appetite affect market implied rating, and their impact on financial institutions' investments in developing countries ${ }^{3}$. The novelty of our hybrid methodology stands in the combination information from data having different frequencies. Therefore, the next section introduces the methodology, the third section presents our results and a last section concludes.

\section{The $\delta$-rating methodology}

This section details how a fundamental rating and a market implied rating are combined. In a first step, the next subsections present the methodologies carried out to evaluate each component. The third subsection outlines the credibility theory approach used to bring together the two elements.

\subsection{Country-Specific Fundamental Rating}

Sovereign credit risk can be captured by a relative small number of economic variables. These do not dramatically differ among studies (Cantor and Packer(1996) 6], Ferri et al.(1999) [12, Mellios and PagetBlanc(2006) [19], etc.). Table 1 summarizes these macroeconomic variables.

\begin{tabular}{|c|c|c|c|}
\hline Variable & Corr. $^{*}$ & Economic Principal & Literature \\
\hline Per capita income & + & $\begin{array}{l}\text { The increase of the per capita income implies } \\
\text { a larger tax base and stronger ability to } \\
\text { honor the debt obligation. }\end{array}$ & $\begin{array}{l}\text { Cantor and Packer (1996) } \\
\text { Ferri et al. (1999) } \\
\text { Mellios and Paget-Blanc (2006) } \\
\text { Gärtner et al. (2011) }\end{array}$ \\
\hline GDP growth rate & + & $\begin{array}{l}\text { The higher growth rate of GDP indicates a } \\
\text { better ability of the country to facing their } \\
\text { debt burden. }\end{array}$ & $\begin{array}{l}\text { Cantor and Packer (1996) } \\
\text { Ferri et al. (1999) } \\
\text { Mellios and Paget-Blanc (2006) } \\
\text { Gärtner et al. (2011) }\end{array}$ \\
\hline Inflation & - & $\begin{array}{l}\text { High inflation rate indicates government } \\
\text { financial structure problem and low } \\
\text { creditworthiness. }\end{array}$ & $\begin{array}{l}\text { Cantor and Packer (1996) } \\
\text { Ferri et al. (1999) } \\
\text { Mellios and Paget-Blanc (2006) } \\
\text { Gärtner et al. (2011) }\end{array}$ \\
\hline Fiscal balance & + & $\begin{array}{l}\text { Fiscal surplus indicates the government has the } \\
\text { financial capacity to pay their debts. Fiscal } \\
\text { deficit indicates less capital to pay the debts. }\end{array}$ & $\begin{array}{l}\text { Cantor and Packer (1996) } \\
\text { Ferri et al. }(1999)^{2} \\
\text { Gärtner et al. }(2011)\end{array}$ \\
\hline External debt & - & $\begin{array}{l}\text { The higher external debt causes higher } \\
\text { intensive to default and lower creditworthiness. }\end{array}$ & $\begin{array}{l}\text { Cantor and Packer (1996) } \\
\text { Ferri et al. }(1999) \\
\text { Gärtner et al. }(2011) \\
\end{array}$ \\
\hline Economic development & + & $\begin{array}{l}\text { Industrialized or developed countries have higher } \\
\text { creditworthiness than the developing countries. }\end{array}$ & $\begin{array}{l}\text { Cantor and Packer (1996) } \\
\text { Ferri et al. (1999) }{ }^{3} \\
\text { Mellios and Paget-Blanc (2006) }\end{array}$ \\
\hline Default History & - & $\begin{array}{l}\text { Defaulting sovereigns suffer a severe } \\
\text { decline in their reputation with creditors. }\end{array}$ & $\begin{array}{l}\text { Ozler(1991) } \\
\text { Cantor and Packer (1996) }\end{array}$ \\
\hline $\begin{array}{l}\text { Current Account Balances } \\
(\mathrm{CAB})\end{array}$ & + & $\begin{array}{l}\text { The larger current account indicates the more } \\
\text { sufficient capital to pay the debt. A persistent } \\
\text { deficit indicates the poor creditworthiness. }\end{array}$ & $\begin{array}{l}\text { Cantor and Packer (1996) } \\
\text { Ferri et al. (1999) } \\
\text { Mellios and Paget-Blanc (2006) }\end{array}$ \\
\hline Corruption Index & + & $\begin{array}{l}\text { Higher index indicate less corruption } \\
\text { and better policy operation. }\end{array}$ & $\begin{array}{l}\text { Mellios and Paget-Blanc (2006) } \\
\text { Michaelides et al. (2012) }\end{array}$ \\
\hline
\end{tabular}

Table 1: Fundamental Explanatory Variables introduced in Literature

\footnotetext{
1 Ferri et al. (1999) use the notation of GDP per capita instead of fiscal Per capital income.

${ }^{2}$ Ferri et al. (1999) use the notation of budget deficit instead of fiscal balance.

3 Ferri et al. (1999) use the notation of development indicator instead of economic development.

4 Cantor and Packer (1996) use the notation external balance refer to the current account deficit.

* "Corr." refers to the correlation between the variable and the creditworthiness of the government. "+" means the bigger the variable the higher the credit. "-" means the lower the variable the higher the credit.

** The literature are not the complete review, we only give relevant references.
}

\footnotetext{
${ }^{3}$ Our empirical analysis covers an extent range of countries and time period which includes the peaks of recent crisis.
} 
Nonetheless, the model used to analyze these variables varies among the studies. Cantor and Packer (1996) [6] tested the variables with cross-sectional date ${ }^{4}$. Ferri et al.(1999) [12] applied panel data $5^{5}$ and did regression analysis with random effect. Mellios and Paget-Blanc (2006) [19] used a principal component analysis (PCA) method, a linear regression and an ordered logistic modeling to analyze the indicators. The relationship between explanatory variables and historical ratings on a special day is not the focal point of this paper, whereas we are interested in the explanatory power of fundamental economic indicators during a relative long period, and panel analysis is more appropriate for this purpose. Therefore, a general panel model is applied to regress fundamental economic indicators on the numerical mappings of agencies' historical rating, which can be expressed by equation (1).

$$
S_{t}=\alpha_{0}+\beta_{1}^{\prime} \cdot X_{t}+\epsilon_{t}^{\prime}
$$

where $\alpha_{0}$ is an intercept vector, $\beta_{1}$ is the coefficients of explanatory variables, $\epsilon_{t}$ is a white noise residual, and $X_{t}$ is a matrix of economic indicators listed in Table 1. $S_{t}$ represents the rating of each sovereign. Parameters and vectors are real numbers. The techniques of analysis used in the empirical study include PCA and panel regression methods. To explore the fittest regression method of equation (1), the pooling regression has been tested against random and cross-sectional effects using Breusch-Pagan Lagrange Multiplier Test(Breusch and Pagan (1980)[4]). Fixed effect against random effect of the selected data will be analyzed using the Hausman Test(Hausman (1978) 14]). The time-fixed effect are tested using both the F-test and the serial correlation using Breusch-Godfrey/Wooldridge test(Godfrey (1996) [16]).

\subsection{Market Implied Rating}

In this study, government bond yields are used as a representation of market perceptions of the risk. Government bonds are a publicly traded financial product. Their prices are related to a government's creditworthiness. Though many papers use credit default swap (CDS) as the proxy of credit risk, these are less resourceful data of CDS than bonds, especially for emerging countries. Secondly, sovereign bond spreads are less subject to liquidity frictions than CDS, therefore they provide a better representation of sovereign risk (Badaoui et al.(2012) 1]). Moreover as highlighted by Hull et al.(2004) [17] bond yield and CDS contain almost the same information, government bond yield is a good proxy of sovereign risk.

Generally, the higher the rating of a sovereign, the lower the bond yields, and vice versa, therefore, bond yields movements can reflect the shift of market attitude towards credit quality of a sovereign. On the other hand, the movements are influenced by other factors than only government repayment capability. When an investor lends money to a government by buying bonds, he exposes himself to many risks, such as credit risk, market risk and liquidity risk. Perraudin and Taylor(2004) 22] have shown that the inconsistencie $\$^{6}$ between credit ratings and corporate bond yields come from non-credit-related factors of spreads such as tax, liquidity and other risk premia. Ejsing et al.(2012)11] discussed liquidity and credit premia for the Euro Zone sovereign bonds. Bonds are traded in the secondary market which simultaneously reflect the market risk perception and deliver timeless information to evaluate the credit risk. Agencies, however, evaluate countries' credit quality on a frequency from quarterly to annually. Hence, some discordances are observed between agencies' ratings and bond yields primarily. Rating agencies advocate that they provide less precise point-in-time measures of risk since the ratings reflect the credit quality in the long term. However, and despite the fact that the previous statement is questionable, market practitioners may be more interested in a short to medium term investments. The inconsistence comes from non-credit reasons rather than only horizon difference.

To improve the analysis, a multi-factor approach is carried out. It is commonly accepted in the literature that credit spreads can be expressed as a linear combination of default-related components and other associated risk premiums (Longstaff and Pedersen(2011) [18, Collin-Dufresne et al.(2001)[7, Beber et al.(2009) 3], etc.). Accordingly, the non-credit-reasons are considered as liquidity risk premium, market

\footnotetext{
${ }^{4}$ Data of forty-nine countries at September 29, 1995

${ }^{5} 10$ years time period (1989-1998) data of seventeen countries

${ }^{6}$ The term "inconsistencies" refers to the disordered ordering classification of average price of bond according to ratings.
} 
demands and investors' risk appetite. Then, yield spreads are decomposed into credit, liquidity, market demand premia and risk appetite using a multi-factor model:

$$
y_{i, t}=a_{i, 0}+a_{i, 1} L_{i, t}+a_{i, 2} M P_{i, t}+a_{i, 3} R A_{i, t}+\varepsilon_{t}
$$

where $y_{i, t}$ refers to yield spreads of bond $i$ at time $t, a_{i, 0}$ represents the averaged credit risk premium, $L_{i, t}$ is the sign of liquidity risk and $M P_{i, t}$ represents the market demand of government bonds and denotes the market appetite, $R A_{i, t}$ measures investors' risk appetite, and $\varepsilon_{t}$ is a standard white noise which is independent from other explanatory variables. Proxies of each indicator in equation (2) are as follow:

1. Bid-ask spreads for liquidity risk,

2. FTSE-Index for the market demand of government bonds

3. Implied volatility of S\&P 500 index options (VIX) for the global risk aversion.

\subsection{Credible Weights}

The " $\delta$-Rating" is obtained through the average of fundamental ratings and market implied ratings using the credibility weight $\omega$. Bühlmann-Straub methoo 7 , the most extensively used and important model in credibility theory, is applied to compute the weight $\omega$ (Bühlmann and Alois(2005)[5]).

Theorem 1 (Bühlmann-Straub). The credibility estimator $\mu$ in the simple Bühlmann-Straub model:

A.1 The random variables $X_{k j}(j=1, \ldots, n)$ are, conditional on $\Theta_{k}=\vartheta$, independent with the same distribution function $F_{\vartheta}$ and conditional moments

$$
\begin{gathered}
\mu(\vartheta)=E\left[X_{k j} \mid \Theta_{k}=\vartheta\right], \\
\sigma^{2}(\vartheta)=\operatorname{Var}\left[X_{k j} \mid \Theta_{k}=\vartheta\right] .
\end{gathered}
$$

A.2 The pairs $\left(\Theta_{1}, X_{1}\right), \ldots,\left(\Theta_{K}, X_{K}\right)$ are independent and identically distributed.

is given by

$$
\mu=\omega \overline{X_{i}}+(1-\omega) \bar{X}
$$

where

$$
\begin{array}{rlrl}
\omega & =\frac{n}{n+\frac{\sigma^{2}}{\tau^{2}}}, & \sigma^{2} & =E\left[\sigma^{2}(\Theta)\right], \quad \tau^{2}=\operatorname{Var}(\mu(\Theta)) . \\
\overline{X_{i}}=\frac{1}{n} \sum_{j=1}^{n} X_{i, j} & \bar{X} & =\frac{1}{K n} \sum_{i=1}^{K} \sum_{j=1}^{n} X_{i j}
\end{array}
$$

Practically, in our case, $\overline{X_{j}}$ is the rating implied by the specific market information and $\bar{X}$ is the long-term fundamental rating estimated through country-specific economic data. Moreover $\omega$ is the weight given to market implied rating and lead to the " $\delta$-rating", as it is the weighted average of the two previous components.

\section{Rating Evaluation: Carrying out the methodology}

\subsection{Country-Specific Implied Rating}

The data used to estimate country-specific rating has annual frequency and belong to the period between 2001 and 2012. Historical rating scores are derived from Fitch Sovereign HistoricalRating $\$^{8}$ using the mapping exhibited in Table 14. Economic indicators, except for the "corruption index", are collected from the International Money Fund (IMF) WEO Database. Corruption Perceptions Index (CPI) has been obtained from Transparency Internationa 9 . The sample includes 20 advanced countries and 8 emerging

\footnotetext{
${ }^{7}$ This approach is also called empirical Bayesian method

8 http://www.fitchratings.com/web_content/ratings/sovereign_ratings_history.xls The annual minimum ratings have been used when there were multiple rating assignments during one year.

${ }^{9}$ Transparency International (2010) Corruption Perceptions Index 2010. Retrieved 24 Aug 2011
} 
countries, according to the IMF classification 10

Statistics of data are presented in Table 8 . The rating of advanced economies are higher than emerging economies'. Advanced economies usually have smaller GPD growth rate, larger external debts, higher per capita income, lower inflation rates, greater fiscal balance, better current account balance and higher corruption perceptions index than emerging economies.

In a first step, the multicollinearity and the correlation of the indicators with the ratings have been analyzed. There is no sufficient evidence supporting a linear relationship between indicators (Figure 1). Moreover, the value of correlations and variance inflation factors (VIF) presented in Table 6 shows that there is no significant multicollinearity. The cumulative explanatory proposition of indicators are given in Table 7 and computed implementing a principal component analysis. The results indicate that the first seven components can explain up to $99 \%$ of the information. The fittest regression method of equation (1) is obtained using the tests introduced in section 2. The tests are implemented on both subgroups of countries and the whole data set. Results are presented in Table 9. The $p$-values of Breusch-Pagan and Breusch-Godfrey/Wooldridge tests indicate that there are cross-sectional dependencies and serial correlations in the advanced economies data set, emerging economies data sets and the whole sample, therefore an OLS regression is not reliable. This is confirmed by using a F-statistic to test fixed effects against the OLS, and Breusch-Pagan LM test of the random effects against the OLS. The $p$-values of Hausman tests reveal that a fixed effect model is more appropriate. The $p$-values of the $F$-tests reject time-fixed effect. Thus, the fixed-effect approach is the best regression method for fundamental rating model (equation 1). The results are presented in Table 2.

External debt (ED) and current account balance (CAB) are significant factors and exhibit negative effects considering advanced economies, emerging economies and the whole data set. The negative effect of ED is consistent with the discussion in Section 2. Indeed, higher external debt causes higher debt burden and leads to lower creditworthiness. A possible explanation of negative $\mathrm{CAB}$ is that domestic investments are financed by foreigners' savings, and this implies a higher confidence in sovereigns' creditworthiness. Although the averaged CAB of advanced countries is higher than of emerging economies, the regression results suggest that the $\mathrm{CAB}$ indicator alone is not sufficient to characterize a country credit quality.

Secondly, the inflation rate (denoted as Inf.) factor is significant for both the whole sample and the emerging economies subsample. It has a negative sign, as a high inflation rate is a negative indicator for the economic development of a country. Investing in countries where the inflation rate is uncontrolled is highly risky. Nevertheless, the causal factor of inflation is ambiguous, especially for the developed countries. It could be the result of a monetary policy aiming at improving the economic condition of a country rather than deteriorating it. However, GDP growth rate, fiscal balance (FB) and Corruption Perceptions Index (CPI) factors are not statistically significant. As a result, the GDP growth rate is not a suitable explanatory variable for rating scores, although it is an important index to characterize the development speed of a country. This result is not entirely counter intuitive as reviewing international GDP growth rate during 2012, we observed that most countries with high GDP growth rate, such as Qatar, Ghana, Turkmenistan, etc., are countries with poor credit quality. On the contrary, countries with good ratings, such as Germany, Finland or Canada, have GDP growth rate under the world average. However, sovereigns with negative growth rate (recession) such as Sudan, Andorra, Syria, etc., are very

\footnotetext{
${ }^{10}$ Though there are plenty of macroeconomic data available for a larger number of countries, it is difficult to collect the market information for the same group of countries. The sample used in this part of analysis is in line with the sample used for the market implied rating. Thus, whether a country is selected in our sample depends on the limit of our access to its pertaining market indicators. Therefore, some interested candidates, such as Greece, China and Argentine are missing.
} 


\begin{tabular}{|c|c|c|c|c|c|c|}
\hline & \multicolumn{2}{|c|}{ All Countries } & \multicolumn{2}{|c|}{ Advanced Countries } & \multicolumn{2}{|c|}{ Emerging Countries } \\
\hline & Estimate & $\operatorname{Pr}(>|t|)$ & Estimate & $\operatorname{Pr}(>|t|)$ & Estimate & $\operatorname{Pr}(>|t|)$ \\
\hline GDP & $\begin{array}{r}0.13 \\
(0.11)\end{array}$ & 0.24 & $\begin{array}{r}0.04 \\
(0.13)\end{array}$ & 0.74 & $\begin{array}{r}0.11 \\
(0.17)\end{array}$ & 0.52 \\
\hline PCI & $\begin{array}{r}4.84 \mathrm{e}-05 \\
(2.89 e-05)\end{array}$ & 0.09 . & $\begin{array}{r}1.64 \mathrm{e}-05 \\
(2.83 e-05)\end{array}$ & 0.56 & $\begin{array}{r}1.68 \mathrm{e}-04 \\
(2.12 e-04)\end{array}$ & 0.43 \\
\hline Inf. & $\begin{array}{r}-0.68 \\
(0.15)\end{array}$ & $1.15 \mathrm{e}-05^{* * *}$ & $\begin{array}{r}-0.12 \\
(0.27)\end{array}$ & 0.65 & $\begin{array}{r}-0.69 \\
(0.20)\end{array}$ & $8.02 \mathrm{e}-04 * * *$ \\
\hline FB & $\begin{array}{r}0.04 \\
(0.17)\end{array}$ & 0.80 & $\begin{array}{r}-0.25 \\
(0.21)\end{array}$ & 0.23 & $\begin{array}{r}0.42 \\
(0.32)\end{array}$ & 0.19 \\
\hline ED & $\begin{array}{l}-0.26 \\
(0.03)\end{array}$ & $<2.2 \mathrm{e}-16^{* * *}$ & $\begin{array}{l}-0.19 \\
(0.03)\end{array}$ & $1.60 \mathrm{e}-09 * * *$ & $\begin{array}{r}-0.47 \\
5.77 e-02\end{array}$ & $4.79 \mathrm{e}-12^{* * *}$ \\
\hline $\mathrm{CAB}$ & $\begin{array}{r}-0.55 \\
(0.11)\end{array}$ & $3.79 \mathrm{e}-07 * * *$ & $\begin{array}{r}-0.35 \\
(0.13)\end{array}$ & $6.64 \mathrm{e}-04^{* *}$ & $\begin{array}{r}-0.80 \\
(0.20)\end{array}$ & $1.02 \mathrm{e}-04 * * *$ \\
\hline CPI & $\begin{array}{r}0.89 \\
(0.78) \\
\end{array}$ & 0.25 & $\begin{array}{r}1.46 \\
(0.93) \\
\end{array}$ & 0.12 & $\begin{array}{r}0.16 \\
(1.44) \\
\end{array}$ & 0.91 \\
\hline Australia & $\begin{array}{r}91.88 \\
(9.33)\end{array}$ & $<2.2 \mathrm{e}-16^{* * *}$ & $\begin{array}{r}96.85 \\
(11.29)\end{array}$ & $<2.2 \mathrm{e}-16^{* * *}$ & - & - \\
\hline Austria & $\begin{array}{r}108.30 \\
(10.99)\end{array}$ & $<2.2 \mathrm{e}-16^{* * *}$ & $\begin{array}{r}113.14 \\
(13.28)\end{array}$ & $<2.2 \mathrm{e}-16^{* * *}$ & - & - \\
\hline Belgium & $\begin{array}{r}108.12 \\
(10.85)\end{array}$ & $<2.2 \mathrm{e}-16^{* * *}$ & $\begin{array}{r}111.55 \\
(13.08)\end{array}$ & $<2.2 \mathrm{e}-16^{* * *}$ & - & - \\
\hline Brazil & $\begin{array}{r}62.10 \\
(7.18)\end{array}$ & $<2.2 \mathrm{e}-16^{* * *}$ & - & - & $\begin{array}{r}65.17 \\
(12.02)\end{array}$ & $5.86 \mathrm{e}-08^{* * *}$ \\
\hline Canada & $\begin{array}{r}109.67 \\
(10.33)\end{array}$ & $<2.2 \mathrm{e}-16^{* * *}$ & $\begin{array}{r}111.21 \\
(12.48)\end{array}$ & $<2.2 \mathrm{e}-16^{* * *}$ & - & - \\
\hline Czech Republic & $\begin{array}{r}81.59 \\
(7.94)\end{array}$ & $<2.2 \mathrm{e}-16^{* * *}$ & $\begin{array}{r}88.53 \\
(9.55)\end{array}$ & $<2.2 \mathrm{e}-16^{* * *}$ & - & - \\
\hline Denmark & $\begin{array}{r}102.39 \\
(12.45)\end{array}$ & $<2.2 \mathrm{e}-16^{* * *}$ & $\begin{array}{r}109.44 \\
(15.06)\end{array}$ & $3.670 \mathrm{e}-13^{* * *}$ & - & - \\
\hline Finland & $\begin{array}{r}101.38 \\
(12.18)\end{array}$ & $<2.2 \mathrm{e}-16^{* * *}$ & $\begin{array}{r}108.13 \\
(14.72)\end{array}$ & $2.058 \mathrm{e}-13^{* * *}$ & - & - \\
\hline France & $\begin{array}{r}108.52 \\
(10.70)\end{array}$ & $<2.2 \mathrm{e}-16^{* * *}$ & $\begin{array}{r}114.61 \\
(12.91)\end{array}$ & $<2.2 \mathrm{e}-16^{* * *}$ & - & - \\
\hline Germany & $\begin{array}{r}110.85 \\
(10.32)\end{array}$ & $<2.2 \mathrm{e}-16^{* * *}$ & $\begin{array}{r}113.83 \\
(12.46)\end{array}$ & $<2.2 \mathrm{e}-16^{* * *}$ & - & - \\
\hline Hungary & $\begin{array}{r}80.50 \\
(9.00)\end{array}$ & $<2.2 \mathrm{e}-16^{* * *}$ & - & - & $\begin{array}{r}79.34 \\
(15.16)\end{array}$ & $1.659 \mathrm{e}-07^{* * *}$ \\
\hline India & $\begin{array}{l}71.96 \\
(4.89)\end{array}$ & $<2.2 \mathrm{e}-16^{* * *}$ & 1110 & (1) $018 * * *$ & $\begin{array}{r}83.10 \\
(8.09)\end{array}$ & $<2.2 \mathrm{e}-16^{* * *}$ \\
\hline Italy & $\begin{array}{r}108.50 \\
(9.52)\end{array}$ & $<2.2 \mathrm{e}-16^{* * *}$ & $\begin{array}{r}111.34 \\
(11.40)\end{array}$ & $<2.2 \mathrm{e}-16^{* * *}$ & - & - \\
\hline Netherlands & $\begin{array}{r}107.02 \\
(10.91)\end{array}$ & $<2.2 \mathrm{e}-16^{* * *}$ & $\begin{array}{r}110.32 \\
(13.18)\end{array}$ & $<2.2 \mathrm{e}-16^{* * *}$ & - & - \\
\hline New Zealand & $\begin{array}{r}101.96 \\
(17.96)\end{array}$ & $<2.2 \mathrm{e}-16 * * *$ & $\begin{array}{r}95.95 \\
(11.47)\end{array}$ & $<2.2 \mathrm{e}-16^{* * *}$ & - & - \\
\hline Norway & $\begin{array}{r}93.2745 \\
(9.48)\end{array}$ & $<2.2 \mathrm{e}-16^{* * *}$ & $\begin{array}{r}114.43 \\
(15.21)\end{array}$ & $<2.2 \mathrm{e}-16^{* * *}$ & - & - \\
\hline Philippines & $\begin{array}{r}65.57 \\
(4.18)\end{array}$ & $<2.2 \mathrm{e}-16^{* * *}$ & - & - & $\begin{array}{r}72.25 \\
(6.77)\end{array}$ & $<2.2 \mathrm{e}-16^{* * *}$ \\
\hline Poland & $\begin{array}{r}81.70 \\
(7.82)\end{array}$ & $<2.2 \mathrm{e}-16^{* * *}$ & - & - & $\begin{array}{r}78.41 \\
(13.14)\end{array}$ & $2.414 \mathrm{e}-09 * * *$ \\
\hline Portugal & $\begin{array}{r}89.25 \\
(9.15)\end{array}$ & $<2.2 \mathrm{e}-16^{* * *}$ & $\begin{array}{r}93.51 \\
(11.03)\end{array}$ & $<2.2 \mathrm{e}-16^{* * *}$ & - & - \\
\hline Russia & $\begin{array}{r}67.29 \\
(7.05)\end{array}$ & $<2.2 \mathrm{e}-16^{* * *}$ & - & - & $\begin{array}{r}60.10 \\
(11.22)\end{array}$ & $8.367 \mathrm{e}-08 * * *$ \\
\hline Singapore & $\begin{array}{l}125.25 \\
(9.19)\end{array}$ & $<2.2 \mathrm{e}-16^{* * *}$ & $\begin{array}{r}116.22 \\
(10.93)\end{array}$ & $<2.2 \mathrm{e}-16^{* * *}$ & - & 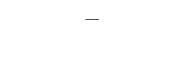 \\
\hline South Africa & $\begin{array}{r}76.78 \\
(6.14)\end{array}$ & $<2.2 \mathrm{e}-16^{* * *}$ & - & - & $\begin{array}{r}77.42 \\
(10.10)\end{array}$ & $2.953 \mathrm{e}-14^{* * *}$ \\
\hline Spain & $\begin{array}{r}96.94 \\
(8.75)\end{array}$ & $<2.2 \mathrm{e}-16^{* * *}$ & $\begin{array}{r}101.18 \\
(10.57)\end{array}$ & $<2.2 \mathrm{e}-16^{* * *}$ & - & - \\
\hline Sweden & $\begin{array}{r}103.56 \\
(11.92)\end{array}$ & $<2.2 \mathrm{e}-16^{* * *}$ & $\begin{array}{r}109.52 \\
(14.40)\end{array}$ & $2.864 \mathrm{e}-14^{* * *}$ & - & - \\
\hline Switzerland & $\begin{array}{l}109.64 \\
(9.94)\end{array}$ & $<2.2 \mathrm{e}-16^{* * *}$ & $\begin{array}{r}110.26 \\
(11.95)\end{array}$ & $<2.2 \mathrm{e}-16^{* * *}$ & - & - \\
\hline Thailand & $\begin{array}{r}81.23 \\
(4.95)\end{array}$ & $<2.2 \mathrm{e}-16^{* * *}$ & - & - & $\begin{array}{r}85.87 \\
(8.09)\end{array}$ & $<2.2 \mathrm{e}-16^{* * *}$ \\
\hline United Kingdom & $\begin{array}{r}103.30 \\
(9.51)\end{array}$ & $<2.2 \mathrm{e}-16^{* * *}$ & $\begin{array}{r}106.17 \\
(11.50)\end{array}$ & $<2.2 \mathrm{e}-16^{* * *}$ & - & - \\
\hline United States & $\begin{array}{l}108.33 \\
(8.73)\end{array}$ & $<2.2 \mathrm{e}-16^{* * *}$ & $\begin{array}{r}109.34 \\
(10.54)\end{array}$ & $<2.2 \mathrm{e}-16^{* * *}$ & - & - \\
\hline $\begin{array}{l}\text { R-Square } \\
\text { Adj. R-Square }\end{array}$ & $\begin{array}{l}0 . \\
0 .\end{array}$ & $\begin{array}{l}7725 \\
3795\end{array}$ & & $\begin{array}{l}517 \\
646\end{array}$ & $\begin{array}{l}0 . \\
0 .\end{array}$ & $\begin{array}{l}8366 \\
7684\end{array}$ \\
\hline
\end{tabular}

The regression is implemented with the data set of all countries, advanced countries and emerging countries respectively. In this table, the coefficient estimate of the corresponding variable is provided in the column labeled "Estimate" along their standard errors in brackets. The p-values are given on the right of each estimate. The symbols "***", "**", "** and "." refer to the significance level $0.001,0.01,0.05$ and 0.1 .

Table 2: Fix-Effect Regression Results for Country-Specific Model 
risky investment choices, as these countries are not creating any value. Consequently, the influence of GDP growth rate on a country credit quality is not linearly related. Though these high scored countries generally have high and positive FB, the difference is not significant in our sample. Regarding the CPI, contrary to the results obtained by Mellios and Paget-Blanc (2006) [19, this factor is positively significant for the whole sample at a $90 \%$ confidence level. Our results indicate that the PCI factor is appropriate to explain the rating scores if the countries are not split in different subsets. Finally, $R^{2}$ and Adjusted $R^{2}$ lie between 0.23 and 0.68 for the estimation of equation $(1)$ on the three data sets. Moreover, $R^{2}$ and adjusted $11 R^{2}$ cannot be improved by changing regression methods. It indicates that using these indicators cannot fully explain the ratings issued by agencies during the recent 10 years. These statistics suggest that during the selected time period some macroeconomic indicators which were explanatory variables in previous analysis cannot explain the rating in ours. This intermediate conclusion should be related to the fact that our analysis is performed during a global downturn and this affects the data. But this support the paper's objective of adjusting this fundamental rating using the market information.

\subsection{Market Implied Rating}

The data used in market implied rating analysis characterized by (2) include bond yields, bid-ask spreads of bond, FTSE-Global Index, and VIX index. These contain the market related information of 20 advanced countries and 8 emerging countries and start from 01/01/2001 to 30/09/2012 on a daily basis. Concretely, the government benchmark bond index provided by Reuters EcoWin with a 10 years maturity, along their local currencies are used to capture bond yields movements. The two main advantages of using this index than computing the term structure of a specific bond are the following. Firstly, it is much easier to match other market indicators with the selected bond yields. Secondly, this bond index is a reference to which investors benchmark the performance of individual market sectors as it is neither polluted by coupons nor taxes. Most bond yield indexes are provided by Reuters EcoWin, however, for some emerging economies, the data have been obtained from Datastream. The bid-ask spreads of bonds have been obtained from Bloomberg. The FTSE-Global Index for each sovereign provided by Reuters EcoWin is used as a proxy for the variation of market demands. VIX indexes obtained from Datastream is used as a measure of the market risk appetite.

Statistics of government benchmark bond index of the selected sovereigns with 10-years maturity are given in Table 10. To facilitate the comparison, a dichotomic approach has been undertaken, splitting advanced and emerging countries into two sub-groups. In average, higher rating leads to lower yields. Consequently, means of high rated sovereigns' bond yields are generally lower than means of those from low rated governments, however, the watershed is not clearly identified. There are intersections of the averaged yields between the high and low rated sovereigns' bond yields. For example, average yields of Thailand who has the highest rating of A/Stable is lower than the mean yields of Australia who are rated AAA/Stable in the period of analysis. Moreover, among the high rated bonds, the movements are not uniform. Figure 2 represents the time series of the government benchmark bond yields of eleven countries whose ratings remained AAA/Stable during the considered period. Although, they hold the same rating during the same period, the movements and ranges of their yields were varying. Switzerland bonds moved relatively smoothly during the observed period, however, on the same period Norway's government bonds fluctuations were significant. Moreover, all bond yields show clear upward movements from 2007 to 2009 except for Canada. Figure 3 exhibits the remaining nine advanced economies' government bond yields. These nine time series show more divers features, since their ratings were varying during this period. Portugal government bond yields experienced the most prominent increase during the last two years. An identical phenomenon has been observed for the government bonds of Belgium, Italy and Spain. However, these countries have been dramatically impacted by resent European Sovereign Debt Crisis (Movements of emerging countries' bond yields are plotted in Figure 4p. Though there is no tendency for these bond yields behaviors, they are more volatile than those of advanced economies.

Chicago Board Options Exchange Volatility Index (VIX) of the same period is presented in Figure 5 . Statistics of bid-ask spread of bonds and market capitalizations of FTSE-Global Equity Index are given

\footnotetext{
${ }^{11}$ Here we assume the linear relation among the variables as model 1
} 
in Table 11. Statistics of these two market indicators are presented in two groups following the country's economic development level. Italian, Portugese and Spanish bonds are relatively more liquid than others among the advanced economies. Meanwhile, the Hungarian, Philippians and Polish bonds are more liquid compared to others emerging countries. The interesting observation in the results presented in the Tables

\begin{tabular}{l|crrrr}
\hline & $\begin{array}{c}\text { Estimates } \\
\text { (Coefficients) }\end{array}$ & Std.Error & t-value & $\operatorname{Pr}(>|t|)$ \\
\hline Ask-Bid Spread & -1.5303 & 0.0098 & -155.5998 & $<2.20 E-16$ & $* * *$ \\
FTSE Maket Cap. & -0.0006 & 0.0001 & -7.9346 & $2.15 \mathrm{E}-15$ & $* * *$ \\
VIX & 0.0018 & 0.0004 & 4.8693 & $1.12 \mathrm{E}-06$ & $* * *$ \\
\hline & Estimates & Std.Error & t-value & $\operatorname{Pr}(>|t|)$ & \\
\hline Australia & Credit Risk Premiums) & & & & \\
Austria & 5.5258 & 0.0183 & 301.8760 & $<2.20 E-16$ & $* * *$ \\
Belgium & 3.9067 & 0.0173 & 226.4240 & $<2.20 E-16$ & $* * *$ \\
Canada & 3.9839 & 0.0173 & 230.1640 & $<2.20 E-16$ & $* * *$ \\
Czech & 4.1206 & 0.0186 & 221.4800 & $<2.20 E-16$ & $* * *$ \\
Denmark & 4.3676 & 0.0172 & 253.2900 & $<2.20 E-16$ & $* * *$ \\
Finland & 3.9283 & 0.0173 & 226.6980 & $<2.20 E-16$ & $* * *$ \\
France & 3.8605 & 0.0173 & 222.5650 & $<2.20 E-16$ & $* * *$ \\
Germany & 3.9276 & 0.0196 & 200.7410 & $<2.20 E-16$ & $* * *$ \\
Italy & 3.7990 & 0.0187 & 203.4140 & $<2.20 E-16$ & $* * *$ \\
Netherland & 4.1761 & 0.0179 & 233.5370 & $<2.20 E-16$ & $* * *$ \\
New Zealand & 3.8647 & 0.0177 & 218.3950 & $<2.20 E-16$ & $* * *$ \\
Norway & 5.8735 & 0.0173 & 340.2560 & $<2.20 E-16$ & $* * *$ \\
Portugal & 4.5459 & 0.0173 & 262.0960 & $<2.20 E-16$ & $* * *$ \\
Singapore & 4.4751 & 0.0182 & 246.5230 & $<2.20 E-16$ & $* * *$ \\
Spain & 2.7923 & 0.0173 & 160.9860 & $<2.20 E-16$ & $* * *$ \\
Sweden & 4.1114 & 0.0179 & 229.8260 & $<2.20 E-16$ & $* * *$ \\
Switzerland & 3.7717 & 0.0175 & 215.3550 & $<2.20 E-16$ & $* * *$ \\
United Kingdom & 2.5913 & 0.0185 & 139.7220 & $<2.20 E-16$ & $* * *$ \\
United States & 4.3938 & 0.0251 & 175.2200 & $<2.20 E-16$ & $* * *$ \\
\hline & 4.6549 & 0.0867 & 53.6620 & $<2.20 E-16$ & $* * *$ \\
\hline & R-Squared: 0.2849 & & $\operatorname{Adj} \mathrm{R}-\mathrm{Squared}: 0.2848$ \\
\hline
\end{tabular}

This table presents the result of the regression of the market implied rating model with the data of 20 advanced economies. Credit risk premia of each country are given in the second column. *** refers significant level 0.001 .

Table 3: Fixed-Effect Regression Results of Market-Implied Rating Model of Advanced Economies

\begin{tabular}{l|rrrc}
\hline & $\begin{array}{r}\text { Estimates } \\
\text { (Coefficients) }\end{array}$ & Std.Error & t-value & $\operatorname{Pr}(>|t|)$ \\
\hline Ask-Bid Spread & 2.8778 & 0.0686 & 41.9800 & $<2.20 E-16^{* * *}$ \\
FTSE Maket Cap. & -0.1210 & 0.0011 & -107.7100 & $<2.20 E-16^{* * *}$ \\
VIX & 0.0344 & 0.0013 & 27.1910 & $<2.20 E-16^{* * *}$ \\
\hline & $\begin{array}{r}\text { Estimates } \\
\text { (Credit Risk Premiums) }\end{array}$ & Std.Error & t-value & $\operatorname{Pr}(>|t|)$ \\
\hline Brazil & 9.7298 & 0.0628 & 154.8320 & $<2.20 E-16^{* * *}$ \\
Hungary & 6.7608 & 0.0692 & 97.6460 & $<2.20 E-16^{* * *}$ \\
India & 7.5942 & 0.0457 & 166.2740 & $<2.20 E-16^{* * *}$ \\
Philippines & 9.1144 & 0.0492 & 185.4130 & $<2.20 E-16^{* * *}$ \\
Poland & 6.0675 & 0.0428 & 141.8240 & $<2.20 E-16^{* * *}$ \\
Russia & 9.2199 & 0.0501 & 184.1090 & $<2.20 E-16^{* * *}$ \\
South Africa & 10.8099 & 0.0484 & 223.4070 & $<2.20 E-16^{* * *}$ \\
Thailand & 4.1275 & 0.0429 & 96.1070 & $<2.20 E-16^{* * *}$ \\
\hline & R-Squared: 0.3505 & & Adj. R-Squared: 0.3503 \\
\hline
\end{tabular}

This table presents the results obtained from the regression of the market implied rating model with the data of 8 emerging economies. Credit risk premia of each country are given in the second column. *** refers significant level 0.001 .

Table 4: Fixed-Effect Regression Results of Market-Implied Rating Model of Emerging Economies

3 and 4, is that the liquidity have different impact on the ratings depending on the group the country belongs to. The results show that liquid bonds issued by advanced economies, i.e. characterized by low bid-ask spreads, bear lower yields. This result is consistent with the fact that the more liquid the asset, 
the lower the transaction costs, the lower the risk, and consequently the lower the return. However, a negative bid-ask spreads has been observed in the result of the regression regarding emerging economies. A possible interpretation of this result is that the liquidity factor for emerging market ${ }^{12}$ works in a different way than for the intuitive approach. When investing in emerging markets, which are relatively riskier than advanced markets, investors may hold more active and sensitive investment strategies than investing in advanced economies. Therefore, even though investors prefer to choose more liquid bonds, they are more sensitive to losses than in advanced market such that they actively trade the bonds. Active trading contributes to a higher liquidity and the yields generated by these bonds are not necessarily very high. Secondly, the market requirement indicator (FTSE-Global Market Capitalization Index) is significant in both regressions with negative signs. This indicates that when investors are willing to invest but are "disappointed" by equity markets, they turn to other markets such as the bonds. Similarly, investors will leave bond market if it becomes depressed. The $p$-values of the $t$-tests confirm that this indicator has a significant influence for the bond yields. While, comparing coefficients of the FTSE Market Cap. in the two regressions, we observe that the influence of market requirements is more significant for the emerging economies than for advanced markets. Finally, the VIX index which measures the risk appetite of market practitioners has a significant positive coefficient in both regressions. This is consistent with the fact that investors tend to be more conservative when the markets are turbulent, i.e. they tend to demand higher returns for the same level of risk under a volatile market than under bullish market conditions. Moreover, the influence of this indicator is stronger for emerging markets than for advanced economies, as people have usually more confidence in advanced economies during crisis (e.g. "fly to quality" behaviors).

\subsection{Implied Ratings and Credibility Weights}

Here, we give the two implied ratings and the $\delta$-ratings in the standard alphabets fashion so that to compare the results with agency's ratings. Country-specific implied rating and market implied rating are derived from previous results listed in Table 2, 3, and 4. The two ratings are both calculated from an ordinal scale method ${ }^{13}$ with the inputs of the previous obtained implied credit premium. The outcomes are credit scores showed in the first two columns of Table 13 . Credibility weights, i.e. $\omega$ in equation 4 are listed in the fifth column of Table $\left.13\right|^{4}$. Alphabets given in Table 5 are the scaled results according to the mapping given in Table 14.

Firstly, fundamental ratings listed in the second column of Table 5 are compared with Fitch's ratings, the last column. Rating agencies tend to rate the advanced countries higher than what is implied by the related economic data, except for the countries affected by crisis like Belgium, Italy, Portugal and Spain. However, this optimistic attitude is not observed evaluating the ratings of emerging countries. Emerging countries with higher agency's ratings than fundamental ratings are usually believed to have good economic perspectives, while those with higher fundamental ratings than agency's ratings usually recently experienced an economic turmoil.

Secondly, we compared market implied ratings and agency's ratings (third and last column in Table 5). Similarly, Fitch gave better ratings to advanced economies than the ratings implied by their market indicators except for the countries believed in trouble, such as Italy, Spain and Portugal. However, this tendency is not particularly clear in the emerging group. Comparing fundamental and market implied ratings, we found that market implied ratings are lower than their fundamental ratings for advanced economies, except for Czech Republic, Portugal and Switzerland. For emerging economies, however, market implied ratings are higher than country-specific implied ratings except for India and South Africa.

Credibility weights are given in Table 13 applying the algorithm expressed in equation (4) and the bootstrapping results of $E\left(\sigma^{2}\right)$. Market implied ratings bear lower weights for the states with stable ratings through years and higher weights for the countries with volatile ratings. The $\delta$-rating provided

\footnotetext{
${ }^{12}$ Or the emerging markets in our sample.

${ }^{13}$ The scales are different since the difference of models of the two ratings. We separate the two economies groups to compute market implied ratings since the different sign of liquidity. Credit rankings are given in Table 12

${ }^{14}$ The value of $\sigma^{2}$ are calculated by bootstrapping.
} 
in the fourth column, are obtained using the credibility weights between the fundamental ratings and the market implied ratings. Comparing the $\delta$-ratings and Fitch's ratings, we observe that the adjusted ratings are usually lower than agency's ratings for advanced economies, but they exhibit different aspects whether the countries are facing financial or economic trouble. This phenomenon indicates that rating agencies may overreact to these countries problems than what their economic and financial indicators imply. For emerging countries, rating agencies give higher ratings to the countries which are believed having better economic perspectives than the averaged ratings we proposed and lower ratings to these countries facing or under economic or financial difficulties. Therefore, we believe ratings agencies are driven by public belief or mass media and partially lose their objectivity. Combining the two implied ratings using credibility weights enables assessing the underlying credit risk of the sovereign.

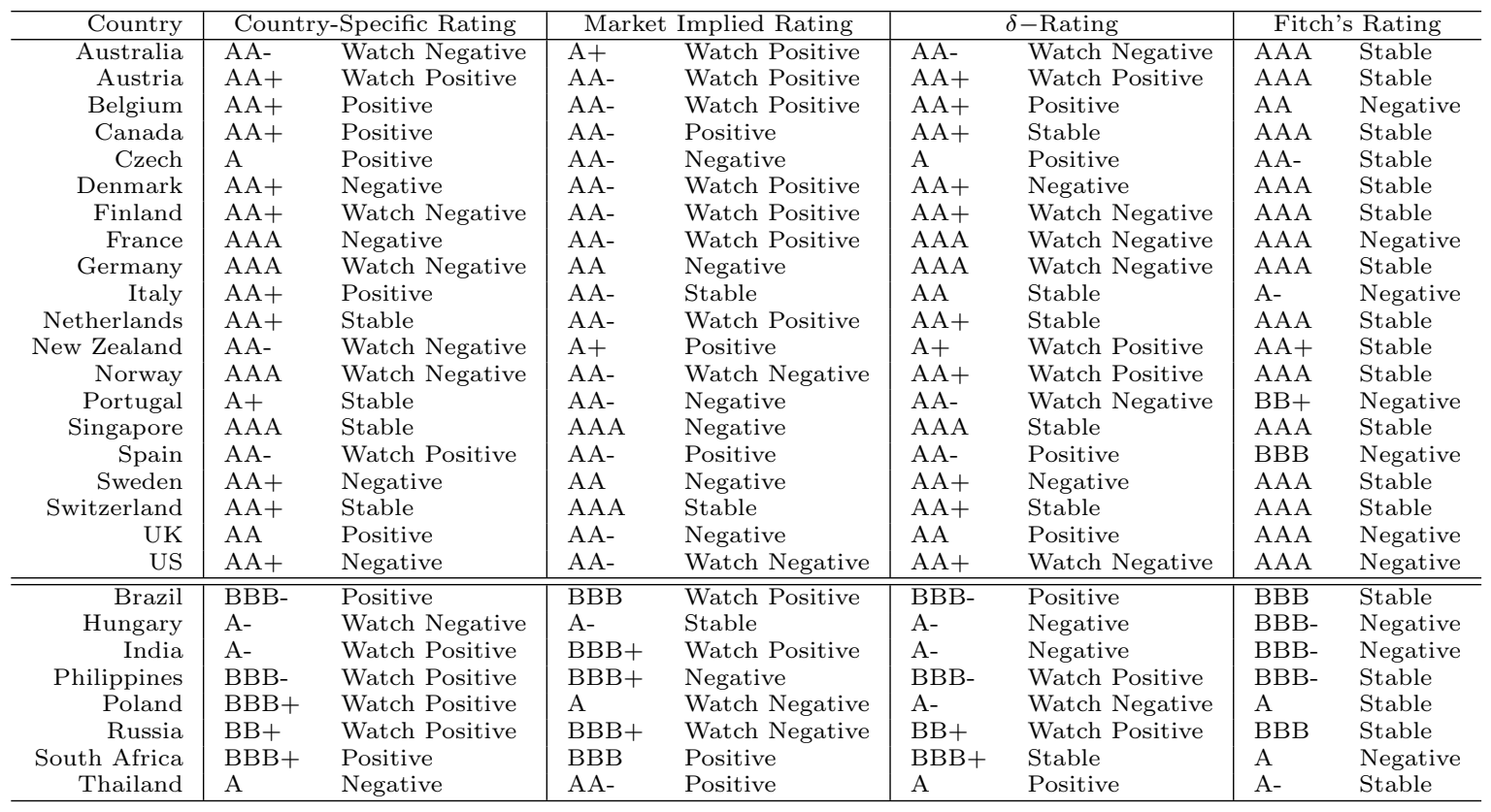

*This table compares the ratings obtained from the different sources. In the first two columns, the country-specific ratings and the market implied ratings of both the 20 advanced economies and the 8 emerging economies are provided using the regression results obtained in the previous section. The weighted averaged ratings obtained using the credibility theory are listed in the third column. The fitch's history rating is given at the last column.

Table 5: Fundament Implied Rating, Market Implied Rating, Adjusted Rating and Agency Rating

\section{Discussion and Conclusion}

As investment opportunities become more global and diverse, it is important to decide which countries represent good investment opportunities. There are advantages to invest in foreign markets, but the risks associated may be considerably higher when investing in emerging economies. To secure the advantage of foreign investment, investors should ensure that the return generated is sufficient to offset the risk they are taking. Measuring the ability of a country to face its financial commitments, i.e. its debts, ratings are essential tools to support investment decisions. Traditional ratings are issued by credit rating agencies (CRAs) which are painfully recovering their credibility after the crisis. The recent remedial regulations such as the Sarbanes-Oxley Act or the Code of Conduct for CRAs ${ }^{15}$ cannot solve the problems completely. Hence, it is necessary to challenge CRAs' fundamental methodologies. In this paper, we proposed an hybrid method using public information to evaluate sovereign's credit. We find several interesting results supporting the idea that investors should rethink the credibility or the objectivity of the ratings issued by CRAs.

\footnotetext{
${ }^{15}$ The code published by the International Organization of Securities Commissions
} 
Firstly, some macroeconomic indicators which have proved to be useful (indeed used by CRAs in their quantitative models) do not really explain the ratings issued by them nowadays. As mentioned above, ratings are a combination of quantitative and qualitative evaluation approach, but the results of countryspecific implied rating in section 3.1 tend to show that agencies' models tend to improve the ratings of advanced economies and lower the ratings of emerging economies. While, it is interesting to notice that there are three exceptions, Italy, Portugal and Spain, who have the agencies' ratings lower than both their country-specific ratings and market implied ratings. This finding confirms the belief that CRAs tend to become more conservative during the crisis and by the way, may adopt a pro-cyclical attitude toward these economies. This attitude justifying the need of alternative approach. Indeed, they tend to give conservative ratings to the countries who are "believed" in trouble even though both economic indicators and market perceptions do not acknowledge them. On the other hand, fundamental rating obtained in our study offers investors an overview of sovereigns credit risk implied by their economic profile. Therefore, an investor holding a long-term investment project may rely more on the fundamental ratings in order to screen the subjective biases released in agencies' ratings.

Secondly, market implied ratings are generally lower than country-specific implied ratings for advanced economies, but higher than the corresponding fundamental ratings for emerging markets. This finding indicates that market has different opinion concerning the difference of credibility between developed and developing sovereigns. Besides, the influence of bond liquidity exhibits different roles in advanced and emerging economies. This outcome suggests that in practice, investors use different trading strategies for emerging markets than for developed economies, since these markets work in another way than the traditional ones. This finding shows that investors who are attracted by the advantages of investing in emerging countries should consider alternative trading strategies than traditional developed markets'. Therefore, investors having a more complex business model should pay more attention to the market implied ratings approach which allows quicker updates regarding the tendency of the uncertain markets. Moreover, the overvalued risk of investing in emerging countries according to CRAs' ratings may offer arbitrage opportunity to short-term oriented investors.

Additionally, the $\delta$-rating approach proposed in this paper gives a weighted average of the long-term fundamental ratings and the updated market implied ratings through credibility weight. We believe the $\delta$-rating can provide better information to investors to make investment decisions. The pure quantitative approach combine the information contained in the low frequency macroeconomic data which provide a long-term through-the-cycle credit evaluation and the timeless market cognition of the risk of investing in the country. The credibility factor grants higher weight to market implied rating when the market is facing turmoil and less weight when the market is stable. We believe the quantitative adjustment from market implied rating is more objective than the qualitative adjustment implemented by rating agencies, and therefore provide better ratings to investors. Accordingly, the $\delta$-rating can correct the subjective biases of agencies' ratings and offer better information to investors to make their investment decision. This statement is even more important, as to optimize a portfolio allocation considering the financial assets issued by the fast growing emerging countries, a more reactive analysis is required.

Furthermore, having used a data set from 2001 to 2012 which covers the turmoil period of the recent European Sovereign-Debt Crisis, our results show that CRAs cannot justify themselves by claiming that they focus on a long-term horizon in using a through-the-cycle rating methodology. Their ratings seems distorted by certain subjective decisions which may be questionable. The statement that they aim to respond only to the perceived permanent component of credit-quality changes is suspect as well since they gives the ratings to Italy, Portugal and Spain lower than the ratings implied by their economic and market indicators. The debt problem experienced by the PIGS (Portugal, Italy, Greece and Spain) justify the concerns, but the pressures from public opinions seems aggravating their predicaments. It is interesting noticing that according to CRAs the PIGS are not investment grade while considering our analysis they are. Consequently, from a credit point of view, the PIGS are ranked among emerging economies. Relying on CRAs may lead to arbitrage opportunities as the yield of bonds issued by the new pool of emerging countries (i.e. PIGS and traditional emerging countries) are too high considering the inherent risk highlighted by our study, therefore, it could be very interesting to invest in these countries, 
as the bonds are under-priced according to our analysis. The crisis of these sovereigns, however, could be chances for investors, since hidden opportunities during crises discovered and highlighted by alternative risk evaluation may be the way to the success. Emerging Markets today will become tomorrow' developed countries. From a credit point of view, without considering any political aspects, these changes may come faster than expected. Besides, considering that some developed countries may do a backward journey toward uncertainty, the definition of emerging countries should be revised, and should be disconnected to the definition underlying investment/ non-investment grade assets.

These results stimulate further interests in studies. Firstly, we have not discussed the problem of forward looking ratings which could be achieved by a quantitative analysis. Since the macroeconomic forecasts for the coming five years from are available from worldwide banks and IMF, we are able to derive a forward looking perspective of country-specific implied ratings. Difficulty may arise from forecasting the market information. Secondly, the correlations between the ratings and the loss given defaults have not been dealt with. We believe these ratings combined practitioners' expectations of the two important factors of counterpart risk. It could be interesting to study the implied default probability and loss given defaults using public available information which is more practicable for investors and risk managers.

Lastly, our studies is limited by the availability of market data for emerging markets. The study will be extended considering a larger group of emerging countries when there are more resourceful data for emerging markets. Furthermore, as some non-linearity in both the fundamental and the market implied models' factors, it will be interesting to extend the methodology to non-linear approaches. 


\section{References}

[1] Badaoui, S., Cathcart and L. El-Jahel, L. (2012) Do sovereign credit default swaps represent a clean measure of sovereign default risk? A factor model approach. SSRN Working papers. UK.

[2] Baek, I.M., Bandopadhyaya, A., and Du, C. (2005) Determinants of market-assessed sovereign risk: Economic fundamentals or market risk appetite? Journal of International Money and Finance, 24, 533-548.

[3] Beber, A., Brandt, M. W., and Kavajecz, K. A. (2009) Filight-to-Quality or Flight-to-Liquidity? Evidence from the Euro-Area Bond Market. Review of Financial Studies, 22(3), 925-957.

[4] Breusch, T.S. and Pagan, A. R. (1980) The Lagrange Multiplier Test and Its Applications to Model Specification in Econometrics, Review of Economic Studies, Wiley Blackwell, 47(1), 239-53.

[5] Bühlmann, H. and Alois G. (2005) A Course in Credibility Theory, Springer-Verlag, New York.

[6] Cantor, R. and Packer, F (1996) Determinants and Impact of Sovereign Credit Ratings. Economic Policy Review. 2(2), 37-53.

[7] Collin-Dufresne, P., Goldstein, R.S., and Martin, J.S. (2001) The Determinants of Credit Spread Changes. The Journal of Finance, 56(6), 2177-2207.

[8] Cunningham, A., Dixon, L. and Hayes, S. (2001) Analysing yield spreads on emerging market sovereign bonds, Financial Stability Review, Bank of England, 175-186. London, UK.

[9] Duffie, D., Pedersen, L.H. and Singleton, K. (2003) Modeling Sovereign Spreads: A Case Study of Russian Debt. The Journal of Finance, 58, 119-159.

[10] Ederington, H.Louis, Yawitz, J.B. and Roberts, B.E. (1987) The information content of bond ratings, Journal of Financial Reserach, 10, 211-226

[11] Ejsing, J, Grothe, M. and Grothe, O. (2012) Liquidity and credit risk premia in government bond yields, European central bank working paper series No. 1440. Frankfurt, Germany.

[12] Ferri, G., Liu, L.-G. and Stiglitz, J.E. (1999) The Procyclical role of rating agencies: Evidence from the east asian crisis, Economic Notes, 3, 335-355.

[13] Gärtner, M., Griesbach, B. and Jung, F. (2011) PIGS or Lambs? The European Sovereign Debt Crisis and the Role of Rating Agencies. International advances in economic research, 17(3), 288-299.

[14] Hausman, J. A. (1978), Specification Tests in Econometrics, Econometrica 46(6), 1251-1271.

[15] Hettenhouse, G. and Sartoris, W. (1976) An Analysis of the Information Value of Bond Rating Changes. Quarterly Review of Economics and Business, 16, 65-78.

[16] Godfrey, L. G. (1996), Misspecification tests and their uses in econometrics. Journal of Statistical Planning and Inference, 49(2), 241-260.

[17] Hull, J., Predescu, M. and White, A. (2004) Journal of Banking \& Finance, 28(11), 2789-2811.

[18] Longstaff, F.A., Pan, J., Pedersen, L.H., and Singleton K.J. (2011) How Sovereign Is Sovereign Credit Risk? American Economic Journal, 3, 75-103.

[19] Mellios, C. and Paget-Blanc, E. (2006) Which Factors Determine Sovereign Credit Ratings? European Journal of Finance, 12(4), 361-377.

[20] Michaelides, A., Milidonis, A., Nishiotis, G. and Papakyriacou, P. (2012) Sovereign Debt Rating Changes and the Stock Market. CEPR Discussion Papers with number 8743. Cyprus.

[21] Ozler, S. (1991) Evolution of Credit Terms: An Empirical Examination of Commercial Bank Lending to Developing Countries. Journal of Development Economics, 38, 79-97. 
[22] Perraudin, W. and Taylor, A. P. (2004) On the Consistency of Ratings and Bond Market yields, Journal of Banking \& Finance, 28(11), 2769 - 2788.

[23] Weinstein, M. (1977) The Effect of a Rating Change Announcement on Bond Price. Journal of Financial Economics, 5, 329-350.

\begin{tabular}{|c|c|c|c|c|c|c|c|c|}
\hline \multicolumn{9}{|c|}{ Advanced Economies } \\
\hline & GDP & PCI & Inf. & $\mathrm{FB}$ & ED & $\mathrm{CAB}$ & CPI & Score \\
\hline GDP & 1.00 & -0.09 & 0.11 & -0.25 & -0.15 & 0.23 & 0.18 & 0.13 \\
\hline PCI & -0.09 & 1.00 & -0.14 & 0.29 & -0.02 & 0.46 & 0.44 & 0.41 \\
\hline Inf. & 0.11 & -0.14 & 1.00 & -0.09 & -0.11 & -0.29 & -0.12 & -0.13 \\
\hline FB & -0.25 & 0.29 & -0.09 & 1.00 & -0.05 & 0.08 & 0.01 & 0.02 \\
\hline ED & -0.15 & -0.02 & -0.11 & -0.05 & 1.00 & 0.19 & -0.30 & -0.23 \\
\hline $\mathrm{CAB}$ & 0.23 & 0.46 & -0.29 & 0.08 & 0.19 & 1.00 & 0.48 & 0.33 \\
\hline CPI & 0.18 & 0.44 & -0.12 & 0.01 & -0.30 & 0.48 & 1.00 & 0.69 \\
\hline Score & 0.13 & 0.41 & -0.13 & 0.02 & -0.23 & 0.33 & 0.69 & 1.00 \\
\hline VIF & 1.29 & 1.57 & 1.14 & 1.20 & 1.53 & 2.32 & 1.91 & \\
\hline \multicolumn{9}{|c|}{ Emerging Economies } \\
\hline & GDP & PCI & Inf. & $\mathrm{FB}$ & ED & $\mathrm{CAB}$ & CPI & Score \\
\hline GDP & 1.00 & -0.36 & 0.08 & -0.30 & 0.02 & 0.09 & -0.32 & -0.12 \\
\hline PCI & -0.36 & 1.00 & -0.11 & 0.81 & -0.15 & -0.29 & 0.52 & 0.41 \\
\hline Inf. & 0.08 & -0.11 & 1.00 & 0.16 & -0.20 & 0.30 & -0.22 & -0.45 \\
\hline FB & -0.30 & 0.81 & 0.16 & 1.00 & -0.09 & -0.21 & 0.50 & 0.23 \\
\hline ED & 0.02 & -0.15 & -0.20 & -0.09 & 1.00 & -0.34 & 0.20 & -0.37 \\
\hline $\mathrm{CAB}$ & 0.09 & -0.29 & 0.30 & -0.21 & -0.34 & 1.00 & -0.73 & -0.46 \\
\hline CPI & -0.32 & 0.52 & -0.22 & 0.50 & 0.20 & -0.73 & 1.00 & 0.54 \\
\hline Score & -0.12 & 0.41 & -0.45 & 0.23 & -0.37 & -0.46 & 0.54 & 1.00 \\
\hline $\mathrm{VIF}$ & 1.23 & 3.84 & 1.38 & 3.89 & 1.28 & 2.60 & 3.21 & \\
\hline \multicolumn{9}{|c|}{ All Sovereigns } \\
\hline & GDP & PCI & Inf. & $\mathrm{FB}$ & ED & CAB & $\mathrm{CPI}$ & Score \\
\hline GDP & 1.00 & -0.35 & 0.30 & -0.41 & -0.16 & 0.12 & -0.28 & -0.32 \\
\hline PCI & -0.35 & 1.00 & -0.50 & 0.56 & 0.11 & 0.37 & 0.77 & 0.75 \\
\hline Inf. & 0.30 & -0.50 & 1.00 & -0.29 & -0.20 & -0.10 & -0.56 & -0.66 \\
\hline $\mathrm{FB}$ & -0.41 & 0.56 & -0.29 & 1.00 & 0.04 & 0.08 & 0.48 & 0.50 \\
\hline ED & -0.16 & 0.11 & -0.20 & 0.04 & 1.00 & 0.12 & 0.02 & 0.02 \\
\hline $\mathrm{CAB}$ & 0.12 & 0.37 & -0.10 & 0.08 & 0.12 & 1.00 & 0.29 & 0.16 \\
\hline CPI & -0.28 & 0.77 & -0.56 & 0.48 & 0.02 & 0.29 & 1.00 & 0.88 \\
\hline Score & -0.32 & 0.75 & -0.66 & 0.50 & 0.02 & 0.16 & 0.88 & 1.00 \\
\hline VIF & 1.38 & 3.26 & 1.63 & 1.63 & 1.13 & 1.37 & 2.95 & \\
\hline
\end{tabular}

* $\mathrm{PCI}$ is per capita income; Inf. means inflation; FB refers to fiscal balance; ED indicates external debt; CAB is the abbreviation of current account balance; CPI is the Corruption Perceptions Index published by Transparency International; DH denotes default history; Score is the numerical value of the corresponding rating. The correlations are computed for all the sovereigns, advanced economies and emerging economies and listed in the three sub-tables.

Table 6: Correlation among Economic Indicators and Rating Scores (2001-2012) 


\begin{tabular}{|c|c|c|c|c|c|c|c|c|}
\hline \multicolumn{9}{|c|}{ Importance of components: } \\
\hline \multicolumn{9}{|c|}{ All Economies } \\
\hline & $\mathrm{PC} 1$ & $\mathrm{PC} 2$ & PC3 & $\mathrm{PC} 4$ & PC5 & PC6 & PC7 & PC8 \\
\hline Standard deviation & 1.9281 & 1.0897 & 1.0377 & 0.8948 & 0.71550 & 0.62213 & 0.46419 & 0.3213 \\
\hline Proportion of Variance & 0.4647 & 0.1484 & 0.1346 & 0.1001 & 0.06399 & 0.04838 & 0.02693 & 0.0129 \\
\hline Cumulative Proportion & 0.4647 & 0.6131 & 0.7477 & 0.8478 & 0.91178 & 0.96017 & 0.98710 & 1.0000 \\
\hline \multicolumn{9}{|c|}{ Advanced Economies } \\
\hline & $\mathrm{PC} 1$ & $\mathrm{PC} 2$ & PC3 & $\mathrm{PC} 4$ & PC5 & PC6 & $\mathrm{PC} 7$ & PC8 \\
\hline Standard deviation & 1.5973 & 1.2271 & 1.1086 & 0.9247 & 0.86485 & 0.68678 & 0.63403 & 0.48714 \\
\hline Proportion of Variance & 0.3189 & 0.1882 & 0.1536 & 0.1069 & 0.09349 & 0.05896 & 0.05025 & 0.02966 \\
\hline Cumulative Proportion & 0.3189 & 0.5071 & 0.6607 & 0.7676 & 0.86113 & 0.92009 & 0.97034 & 1.00000 \\
\hline \multicolumn{9}{|c|}{ Emerging Economies } \\
\hline & $\mathrm{PC} 1$ & $\mathrm{PC} 2$ & PC3 & $\mathrm{PC} 4$ & PC5 & $\mathrm{PC} 6$ & PC7 & PC8 \\
\hline Standard deviation & 1.7672 & 1.2814 & 1.1289 & 0.9353 & 0.7818 & 0.46764 & 0.37059 & 0.34435 \\
\hline Proportion of Variance & 0.3904 & 0.2053 & 0.1593 & 0.1094 & 0.0764 & 0.02734 & 0.01717 & 0.01482 \\
\hline Cumulative Proportion & 0.3904 & 0.5956 & 0.7549 & 0.8643 & 0.9407 & 0.96801 & 0.98518 & 1.00000 \\
\hline
\end{tabular}

This table gives the principle component analysis results of the economic indicators listed in Table 1 with the three sample sets. Here PC1 to PC8 refers to Rating Scores, GDP growth rate, Per capita income, inflation rate, fiscal balance, external debts, current balance accounts, and corruption perceptions index.

Table 7: Principle Component Analysis of Economic Indicators (2001-2012)

\begin{tabular}{|c|c|c|c|c|c|c|c|c|c|c|}
\hline & GDP & $\mathrm{PCI}^{*}$ & Inf. $^{*}$ & $\mathrm{FB}^{*}$ & $\mathrm{ED}^{*}$ & $\mathrm{CAB}^{*}$ & $\mathrm{CPI}^{*}$ & $\mathrm{DH}^{*}$ & Score $^{*}$ & Rating \\
\hline \multicolumn{11}{|c|}{ Advanced Economies } \\
\hline Min & -8.3540 & 6270 & -0.903 & 18.01 & 9.709 & -12.638 & 3.700 & 0.0 & 49.00 & AA-/stable \\
\hline 1st $\mathrm{Qu}$ & 0.7505 & 27146 & 1.575 & 36.47 & 42.511 & -3.201 & 7.100 & 0.0 & 99.00 & - \\
\hline Median & 1.9195 & 37293 & 2.184 & 43.58 & 58.422 & 1.012 & 8.500 & 0.5 & 100.00 & - \\
\hline Mean & 1.7465 & 38335 & 2.180 & 42.60 & 60.735 & 1.847 & 7.921 & 0.5 & 96.72 & - \\
\hline 3rd Qu. & 3.0595 & 46329 & 2.784 & 49.59 & 77.138 & 5.788 & 9.000 & 1.0 & 100.00 & - \\
\hline Max. & 14.7630 & 99665 & 6.612 & 58.53 & 123.357 & 25.813 & 9.900 & 1.0 & 100.00 & AAA/stable \\
\hline \multicolumn{11}{|c|}{ Emerging Economies } \\
\hline Min. & -7.800 & 467.2 & -0.846 & $\overline{17.00}$ & 7.876 & 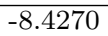 & 2.300 & 1 & 26.0 & BBB-/negative \\
\hline 1st Qu. & 2.851 & 2118.7 & 3.703 & 20.28 & 40.096 & -3.3453 & 2.700 & 1 & 54.0 & - \\
\hline Median & 4.325 & 5080.5 & 4.944 & 31.84 & 50.806 & -0.2730 & 3.500 & 1 & 62.5 & - \\
\hline Mean & 4.194 & 5861.7 & 5.871 & 30.27 & 51.529 & -0.1983 & 3.652 & 1 & 61.8 & - \\
\hline 3rd Qu. & 6.118 & 8768.7 & 7.099 & 38.58 & 66.929 & 2.8727 & 4.525 & 1 & 74.0 & - \\
\hline Max. & 10.623 & 15354.3 & 21.461 & 52.40 & 84.300 & 11.0690 & 5.500 & 1 & 80.0 & A/stable \\
\hline \multicolumn{11}{|c|}{ All Countries } \\
\hline Min. & -8.3540 & 467.2 & -0.903 & 17.00 & 7.876 & -12.638 & 2.300 & 0.0000 & 26.00 & BBB-/negative \\
\hline 1st Qu. & 0.9423 & 11248.1 & 1.780 & 33.78 & 41.700 & -3.248 & 4.600 & 0.0000 & 75.00 & - \\
\hline Median & 2.5165 & 30152.8 & 2.479 & 39.34 & 55.836 & 0.285 & 7.300 & 1.0000 & 100.00 & - \\
\hline Mean & 2.4459 & 29056.8 & 3.234 & 39.08 & 58.105 & 1.262 & 6.701 & 0.6429 & 86.75 & - \\
\hline 3rd Qu. & 3.9000 & 43394.7 & 3.814 & 47.68 & 72.164 & 4.697 & 8.800 & 1.0000 & 100.00 & - \\
\hline Max. & 14.7630 & 99664.5 & 21.461 & 58.53 & 123.357 & 25.813 & 9.900 & 1.0000 & 100.00 & AAA/stable \\
\hline
\end{tabular}

* In this table, PCI is the per capita income; Inf. means inflation; FB refers to fiscal balance; ED indicates external debt; CAB is the abbreviation of current account balance; CPI is the Corruption Perceptions Index published by Transparency International; DH denotes default history; Score is the numerical value of the corresponding rating. It includes 20 advanced economies: Australia, Austria, Belgium, Canada, Czech, Denmark, Finland, France, Germany, Italy, Netherland, New Zealand, Norway, Portugal, Singapore, Spain, Sweden, Switzerland, United Kingdom, United States; and 8 emerging economies: Brazil, Hungary, India, Philippines, Poland, Russia, South Africa and Thailand. The data is from 2001 to 2012, annually.

Table 8: Statistics of Economic Indicator Data (2001-2012) 


\begin{tabular}{|c|c|c|c|c|c|c|}
\hline & Fixed vs. OLS & Fixed or Random & Time-fixed & Random or OLS & Cross-sectional & Serial Correlation \\
\hline & F Test & Hausman Test & F Test & $\begin{array}{c}\text { Breusch-Pagan } \\
\text { LM Test }\end{array}$ & $\begin{array}{c}\text { Breusch-Pagan } \\
\text { LM Test }\end{array}$ & $\begin{array}{l}\text { Breusch-Godfrey/ } \\
\text { Wooldridge Test }\end{array}$ \\
\hline $\begin{array}{l}\text { Advanced } \\
\text { Economies }\end{array}$ & $\begin{array}{c}\mathrm{F}=9.61 \\
\mathrm{df} 1=18 \\
\mathrm{df} 2=213 \\
\mathrm{p}-\text { value }<2.2 \mathrm{e}-16\end{array}$ & $\begin{array}{c}\text { chisq }=37.35 \\
\mathrm{df}=7 \\
\mathrm{p}-\mathrm{value}= \\
4.03 \mathrm{e}-06\end{array}$ & $\begin{array}{c}\mathrm{F}=1.22 \\
\mathrm{df} 1=11 \\
\mathrm{df} 2=202 \\
\mathrm{p} \text {-value }=0.28\end{array}$ & $\begin{array}{c}\text { chisq }=69.41 \\
\text { df }=1 \\
\text { p-value }< \\
2.2 \mathrm{e}-16\end{array}$ & $\begin{array}{c}\text { chisq }=605.93 \\
\mathrm{df}=190 \\
\mathrm{p} \text {-value }< \\
2.2 \mathrm{e}-16\end{array}$ & $\begin{array}{c}\text { chisq }=69.93 \\
\mathrm{df}=12 \\
\mathrm{p}-\mathrm{value}= \\
3.3 \mathrm{e}-10\end{array}$ \\
\hline $\begin{array}{l}\text { Emerging } \\
\text { Economies }\end{array}$ & $\begin{array}{c}\mathrm{F}=20.81 \\
\mathrm{df} 1=7 \\
\mathrm{df} 2=81 \\
\text { p-value }<9.44 \mathrm{e}-16\end{array}$ & $\begin{array}{c}\text { chisq }=3.43 \\
\mathrm{df}=6 \\
\text { p-value }= \\
1.83 \mathrm{e}-11\end{array}$ & $\begin{array}{c}\mathrm{F}=1.33 \\
\mathrm{df} 1=11 \\
\mathrm{df} 2=70 \\
\mathrm{p} \text {-value }=0.23\end{array}$ & $\begin{array}{c}\text { chisq }=159.34 \\
\mathrm{df}=1 \\
\mathrm{p}-\mathrm{value}< \\
2.2 \mathrm{e}-16\end{array}$ & $\begin{array}{c}\text { chisq }=65.84 \\
\mathrm{df}=28 \\
\mathrm{p} \text {-value }= \\
6.95 \mathrm{e}-05\end{array}$ & $\begin{array}{c}\text { chisq }=40.20 \\
\mathrm{df}=12 \\
\text { p-value }= \\
6.66 \mathrm{e}-05\end{array}$ \\
\hline $\begin{array}{c}\text { All } \\
\text { Countries }\end{array}$ & $\begin{array}{c}\mathrm{F}=26.75 \\
\mathrm{df} 1=26 \\
\mathrm{df} 2=301 \\
\mathrm{p}-\text { value }<2.2 \mathrm{e}-16\end{array}$ & $\begin{array}{c}\text { chisq }=97.18 \\
\text { df }=7 \\
\text { p-value } \\
2.2 \mathrm{e}-16\end{array}$ & $\begin{array}{c}F=1.64 \\
\text { df } 1=11 \\
\text { df } 2=290 \\
\text { p-value }=0.09\end{array}$ & $\begin{array}{c}\text { chisq }=468.72 \\
\mathrm{df}=1 \\
\text { p-value }< \\
2.2 \mathrm{e}-16\end{array}$ & $\begin{array}{c}\text { chisq }=1137.98 \\
\mathrm{df}=378 \\
\mathrm{p}-\mathrm{value}< \\
2.2 \mathrm{e}-16\end{array}$ & $\begin{array}{c}\text { chisq }=143.84 \\
\text { df }=12 \\
\text { p-value }< \\
2.2 \mathrm{e}-16\end{array}$ \\
\hline
\end{tabular}

* Breusch-Pagan Lagrange Multiplier method tests the pooling regression vs. random effect; The Hausman Test checks the fixed effect vs. the random effect. The Breusch-Pagan Lagrange Multiplier test checks the cross-sectional effect. The time-fixed effect is tested using an F-test and the serial correlation is tested using the Breusch-Godfrey/Wooldridge test. All the tests are implemented on the entire data set, the advanced economies and the emerging countries.

Table 9: Tests for Regression Method of Country-Specific Model

\begin{tabular}{|c|c|c|c|c|c|c|c|c|c|c|}
\hline & & Min & 1st Qu. & Median & Mean & 3rd Qu. & Max & Std. & Highest Rating & Lowest Rating \\
\hline 1 & Australia & 2.73 & 5.21 & 5.51 & 5.39 & 5.81 & 6.79 & 0.70 & AAA/Stable & AAA/Stable \\
\hline 2 & Austria & 1.87 & 3.50 & 4.02 & 3.96 & 4.42 & 5.47 & 0.74 & AAA/Stable & AAA/Stable \\
\hline 3 & Belgium & 2.47 & 3.71 & 4.14 & 4.13 & 4.46 & 5.88 & 0.61 & $\mathrm{AA}+/$ Stable & AA-/Stable \\
\hline 4 & Canada & 1.58 & 3.37 & 4.11 & 4.00 & 4.74 & 5.97 & 1.01 & AAA/Stable & AAA/Stable \\
\hline 5 & Czech & 2.29 & 3.77 & 4.22 & 4.38 & 4.85 & 7.27 & 0.91 & AA-/Positive & A/Stable \\
\hline 6 & Denmark & 0.97 & 3.35 & 3.97 & 3.83 & 4.48 & 5.51 & 0.98 & AAA/Stable & AAA/Stable \\
\hline 7 & Finland & 1.34 & 3.36 & 3.95 & 3.85 & 4.39 & 5.48 & 0.85 & AAA/Stable & AAA/Stable \\
\hline 8 & France & 2.06 & 3.46 & 3.94 & 3.91 & 4.36 & 5.35 & 0.69 & AAA/Stable & AAA/Negative \\
\hline 9 & Germany & 1.16 & 3.19 & 3.85 & 3.67 & 4.28 & 5.28 & 0.90 & AAA/Stable & AAA/Stable \\
\hline 10 & Italy & 3.21 & 4.08 & 4.43 & 4.55 & 4.92 & 7.30 & 0.68 & AA/Stable & A-/Negative \\
\hline 11 & Netherlands & 1.54 & 3.39 & 3.93 & 3.84 & 4.36 & 5.40 & 0.82 & AAA/Stable & AAA/Stable \\
\hline 12 & New Zealand & 3.24 & 5.66 & 5.94 & 5.79 & 6.24 & 7.03 & 0.76 & AAA/Stable & $\mathrm{AA}+/$ Stable \\
\hline 13 & Norway & 1.61 & 3.69 & 4.24 & 4.37 & 4.96 & 6.97 & 1.17 & AAA/Stable & AAA/Stable \\
\hline 14 & Portugal & 3.10 & 4.07 & 4.46 & 5.39 & 5.24 & 17.36 & 2.50 & AA/Stable & BB-/Negative \\
\hline 15 & Singapore & 1.30 & 2.37 & 2.86 & 2.82 & 3.38 & 4.13 & 0.68 & AAA/Stable & AAA/Stable \\
\hline 16 & Spain & 3.00 & 3.96 & 4.27 & 4.46 & 5.02 & 7.64 & 0.75 & AAA/Stable & BBB/Negative \\
\hline 17 & Sweden & 1.13 & 3.20 & 3.87 & 3.80 & 4.59 & 5.77 & 1.05 & AAA/Stable & AAA/Stable \\
\hline 18 & Switzerland & 0.45 & 1.97 & 2.44 & 2.36 & 2.86 & 3.73 & 0.74 & AAA/Stable & AAA/Stable \\
\hline 19 & United Kingdom & 1.44 & 3.69 & 4.49 & 4.18 & 4.84 & 5.58 & 0.92 & AAA/Stable & AAA/Negative \\
\hline 20 & United States & 1.39 & 3.40 & 4.07 & 3.90 & 4.60 & 5.51 & 0.95 & AAA/Stable & AAA/Negative \\
\hline 1 & Brazil & 2.26 & 5.10 & 6.38 & 8.19 & 10.44 & 30.78 & 4.76 & BBB/Stable & $\mathrm{B}+/$ Negative \\
\hline 2 & India & 4.96 & 6.92 & 7.62 & 7.50 & 8.15 & 10.82 & 1.15 & $\mathrm{~A}+/$ Stable & BBB-/Negative \\
\hline 3 & Hungary & 5.49 & 7.04 & 7.54 & 7.72 & 8.22 & 12.72 & 1.00 & BBB-/Stable & $\mathrm{BB}+/$ Stable \\
\hline 4 & Philippine & 4.85 & 7.23 & 8.75 & 9.84 & 12.48 & 18.64 & 3.16 & BBB/Stable & $\mathrm{BB}+/$ Negative \\
\hline 5 & Poland & 4.39 & 5.50 & 5.90 & 6.37 & 6.47 & 12.54 & 1.57 & $\mathrm{~A}+/$ Stable & A/Stable \\
\hline 6 & Russia & 6.26 & 6.84 & 7.91 & 8.36 & 9.43 & 18.90 & 1.90 & $\mathrm{BBB}+/$ Stable & B- \\
\hline 7 & South Africa & 6.44 & 8.06 & 8.67 & 9.07 & 9.80 & 13.50 & 1.39 & A/Positive & $\mathrm{BBB}+/$ Stable \\
\hline 8 & Thailand & 2.35 & 3.73 & 4.42 & 4.42 & 5.07 & 6.84 & 0.88 & A/Stable & $\mathrm{BBB}+/$ Stable \\
\hline
\end{tabular}

*There are statistics of 20 advanced economies and 8 emerging economies government benchmark bond yields with 10 years maturity. 1st Qu. and 3rd Qu. means the first quartile and third quartile; Std. refers to the standard error. The data set starts from Jan. 2001 to Sep. 2012. We give the highest rating and lowest rating from Fitch History Rating during this period in the last two columns. For the lack of data, the statistics of Philippine and Russia start from 16/01/2001 and 21/03/2003 respectively.

Table 10: Statistics of Government Benchmarks 10 Year Bond Yields of 28 Countries (2001-2012) 


\begin{tabular}{|c|c|c|c|c|c|c|c|c|c|c|c|}
\hline & & \multicolumn{5}{|c|}{ Ask-Bid Spreads } & \multicolumn{5}{|c|}{ FTSE Global Market CAP } \\
\hline & & Min & Median & Mean & Max & Std & Min & Median & Mean & $\operatorname{Max}$ & Std \\
\hline 1 & Australia & 0.99 & 1.09 & 1.10 & 1.32 & 0.04 & 20.42 & 61.88 & 63.07 & 111.28 & 27.34 \\
\hline 2 & Austria & 0.61 & 1.02 & 0.99 & 1.12 & 0.08 & 0.75 & 3.40 & 3.61 & 8.90 & 2.12 \\
\hline 3 & Belgium & 0.31 & 1.01 & 0.94 & 1.08 & 0.15 & 3.59 & 7.83 & 8.04 & 12.11 & 1.86 \\
\hline 4 & Canada & 0.87 & 1.07 & 1.08 & 1.24 & 0.05 & 26.92 & 78.68 & 74.44 & 134.39 & 28.98 \\
\hline 5 & Czech & 0.78 & 1.00 & 1.02 & 1.42 & 0.13 & 0.17 & 1.41 & 1.24 & 3.24 & 0.77 \\
\hline 6 & Denmark & 0.97 & 1.08 & 1.09 & 1.54 & 0.08 & 3.80 & 8.55 & 9.17 & 16.29 & 3.29 \\
\hline 7 & Finland & 0.84 & 1.03 & 1.03 & 1.27 & 0.04 & 6.58 & 11.75 & 12.62 & 26.39 & 3.85 \\
\hline 8 & France & 0.62 & 1.03 & 1.00 & 1.12 & 0.08 & 46.85 & 100.92 & 104.75 & 179.16 & 31.70 \\
\hline 9 & Germany & 1.02 & 1.07 & 1.09 & 1.39 & 0.90 & 28.60 & 75.69 & 76.89 & 138.34 & 24.65 \\
\hline 10 & Italy & 0.06 & 0.99 & 0.86 & 1.04 & 0.24 & 19.24 & 35.54 & 38.37 & 65.67 & 12.21 \\
\hline 11 & Netherland & 0.84 & 1.03 & 1.03 & 1.15 & 0.04 & 15.80 & 35.90 & 36.31 & 57.24 & 8.77 \\
\hline 12 & New Zealand & 0.92 & 1.09 & 1.08 & 1.22 & 0.06 & 0.79 & 1.63 & 1.63 & 2.55 & 0.42 \\
\hline 13 & Norway & 1.02 & 1.12 & 1.15 & 1.60 & 0.11 & 2.58 & 7.52 & 7.61 & 16.34 & 3.58 \\
\hline 14 & Portugal & 0.00 & 1.01 & 0.82 & 1.06 & 0.35 & 1.88 & 3.52 & 3.76 & 6.87 & 1.10 \\
\hline 15 & Singapore & 0.75 & 1.00 & 1.00 & 1.18 & 0.01 & 4.14 & 10.13 & 12.10 & 23.00 & 5.66 \\
\hline 16 & Spain & 0.04 & 1.02 & 0.89 & 1.09 & 0.27 & 16.35 & 39.96 & 39.71 & 73.11 & 14.21 \\
\hline 17 & Sweden & 0.75 & 1.01 & 1.00 & 1.24 & 0.03 & 9.39 & 25.73 & 25.44 & 43.04 & 8.43 \\
\hline 18 & Switzerland & 1.00 & 1.14 & 1.17 & 1.69 & 0.10 & 34.96 & 72.44 & 70.89 & 101.92 & 17.67 \\
\hline 19 & United Kingdom & 0.94 & 1.08 & 1.08 & 1.28 & 0.04 & 118.8 & 224.4 & 225.0 & 345.1 & 48.68 \\
\hline 20 & United States & 0.95 & 1.10 & 1.10 & 1.22 & 0.04 & 642.3 & 1142.8 & 1131.3 & 1513.1 & 196.30 \\
\hline 1 & Brazil & 1.16 & 1.72 & 1.74 & 2.13 & 0.16 & 3.12 & 27.15 & 32.04 & 75.75 & 23.44 \\
\hline 2 & India & 2.72 & 2.72 & 2.72 & 2.72 & $5.70 \mathrm{E}-07$ & 3.68 & 27.23 & 24.63 & 46.10 & 12.06 \\
\hline 3 & Hungary & 0.69 & 0.96 & 0.95 & 1.16 & 0.08 & 0.36 & 1.65 & 1.65 & 3.60 & 0.82 \\
\hline 4 & Philippine & 0.38 & 0.73 & 0.73 & 1.08 & 0.16 & 0.34 & 1.00 & 1.16 & 3.38 & 0.73 \\
\hline 5 & Poland & 0.72 & 0.98 & 0.96 & 1.13 & 0.06 & 0.64 & 2.68 & 2.78 & 6.44 & 1.65 \\
\hline 6 & Russia & 0.49 & 1.23 & 1.23 & 1.80 & 0.15 & 2.59 & 20.10 & 17.66 & 40.29 & 10.35 \\
\hline 7 & South Africa & 0.91 & 1.00 & 1.01 & 1.15 & 0.04 & 4.41 & 22.34 & 20.89 & 38.52 & 10.21 \\
\hline 8 & Thailand & 0.61 & 0.99 & 1.00 & 1.50 & 0.13 & 0.59 & 3.30 & 3.53 & 8.86 & 2.12 \\
\hline
\end{tabular}

* Market capitalizations of the country's equity market issued by FTSE-Global Equity Index for each sovereign are normalized into the common scale as bond yields and liquidity spreads. Statistics of two market indicators of the 28 economies. The Bid-Ask spread is calculated using the following formula: $\frac{\text { Ask-Bid }}{\text { Ask }} \times 100 \%$ using data collected from Bloomberg. The equity market capitalizations of sovereign is measured by the FTSE-Global market cap index. Std means standard deviation. These data start from Jan. 2001 to Sep. 2012. The data of Philippine and Russia follow the same period as the data of their government benchmark bond yields. They are all daily data.

Table 11: Statistics of Market Indicators (2001-2012) 


\begin{tabular}{|c|c|c|c|}
\hline & Country-Specific Rank & Market Implied Rank & Rank Splits \\
\hline \multicolumn{4}{|c|}{ Advanced Economies } \\
\hline Australia & 17 & 19 & 2 \\
\hline Austria & 5 & 7 & 2 \\
\hline Belgium & 6 & 10 & 4 \\
\hline Canada & 8 & 12 & 4 \\
\hline Czech Republic & 20 & 14 & -6 \\
\hline Denmark & 12 & 9 & -3 \\
\hline Finland & 14 & 5 & -9 \\
\hline France & 2 & 8 & 6 \\
\hline Germany & 4 & 4 & 0 \\
\hline Italy & 7 & 13 & 6 \\
\hline Netherlands & 9 & 6 & -3 \\
\hline New Zealand & 18 & 20 & 2 \\
\hline Norway & 3 & 17 & 14 \\
\hline Portugal & 19 & 16 & -3 \\
\hline Singapore & 1 & 2 & 1 \\
\hline Spain & 16 & 11 & -5 \\
\hline Sweden & 11 & 3 & -8 \\
\hline Switzerland & 10 & 1 & -9 \\
\hline United Kingdom & 15 & 15 & 0 \\
\hline United States & 13 & 18 & 5 \\
\hline \multicolumn{4}{|c|}{ Emerging Economies } \\
\hline Brazil & 7 & 7 & 0 \\
\hline Hungary & 3 & 3 & 0 \\
\hline India & 4 & 2 & -2 \\
\hline Philippines & 5 & 6 & 1 \\
\hline Poland & 2 & 4 & 2 \\
\hline Russia & 6 & 8 & 2 \\
\hline South Africa & 8 & 5 & -3 \\
\hline Thailand & 1 & 1 & 0 \\
\hline
\end{tabular}

In this table, the implied credit ranks of the 20 advanced economies and the 8 selected emerging economies have been provided. The number in the first column is the country-specific ranks computed from the results of Table 2 The market implied ranks are listed in the second column calculated from the implied credit premium in Table 3 and 4 In the last column, the differences between the two ranks have been provided.

Table 12: Country-Specific Implied and Market Implied Ranks 


\begin{tabular}{|c|c|c|c|c|c|c|}
\hline Country & Fundamental Score & Market Score & Averaged Scores & Fitch's Score & $\delta$-Socre & Weight \\
\hline Australia & 0.83 & 0.82 & 0.83 & 1.00 & 0.83 & 0.311901195 \\
\hline Austria & 0.97 & 0.87 & 0.92 & 1.00 & 0.97 & 0.039688222 \\
\hline Belgium & 0.96 & 0.87 & 0.91 & 0.89 & 0.96 & 0.003523232 \\
\hline Canada & 0.96 & 0.86 & 0.91 & 1.00 & 0.95 & 0.056833804 \\
\hline Czech Republic & 0.76 & 0.84 & 0.80 & 0.85 & 0.76 & 0.007325898 \\
\hline Denmark & 0.94 & 0.87 & 0.91 & 1.00 & 0.94 & 0.050539811 \\
\hline Finland & 0.93 & 0.87 & 0.90 & 1.00 & 0.93 & 0.057606644 \\
\hline France & 0.99 & 0.87 & 0.93 & 0.99 & 0.98 & 0.023910266 \\
\hline Germany & 0.98 & 0.89 & 0.93 & 1.00 & 0.98 & 0.019197356 \\
\hline Italy & 0.96 & 0.85 & 0.90 & 0.69 & 0.90 & 0.529180125 \\
\hline Netherlands & 0.95 & 0.87 & 0.91 & 1.00 & 0.95 & 0.044894827 \\
\hline New Zealand & 0.83 & 0.81 & 0.82 & 0.95 & 0.82 & 0.122773553 \\
\hline Norway & 0.98 & 0.83 & 0.91 & 1.00 & 0.97 & 0.104713107 \\
\hline Portugal & 0.80 & 0.84 & 0.82 & 0.49 & 0.83 & 0.851728728 \\
\hline Singapore & 1.00 & 0.99 & 1.00 & 1.00 & 1.00 & $1.23082 \mathrm{E}-06$ \\
\hline Spain & 0.87 & 0.86 & 0.87 & 0.59 & 0.86 & 0.736500433 \\
\hline Sweden & 0.94 & 0.89 & 0.92 & 1.00 & 0.94 & 0.028099158 \\
\hline Switzerland & 0.95 & 1.00 & 0.97 & 1.00 & 0.95 & 0.00088457 \\
\hline United Kingdom & 0.91 & 0.84 & 0.88 & 0.99 & 0.91 & 0.091735941 \\
\hline United States & 0.94 & 0.83 & 0.89 & 0.99 & 0.93 & 0.095308758 \\
\hline Brazil & 0.56 & 0.62 & 0.59 & 0.60 & 0.56 & 0.002671929 \\
\hline Hungary & 0.68 & 0.7 & 0.69 & 0.54 & 0.69 & 0.626134691 \\
\hline India & 0.72 & 0.67 & 0.69 & 0.54 & 0.69 & 0.644876707 \\
\hline Philippines & 0.62 & 0.64 & 0.63 & 0.55 & 0.62 & 0.113775216 \\
\hline Poland & 0.67 & 0.73 & 0.70 & 0.75 & 0.68 & 0.027353724 \\
\hline Russia & 0.52 & 0.63 & 0.57 & 0.60 & 0.52 & 0.051003205 \\
\hline South Africa & 0.66 & 0.61 & 0.64 & 0.74 & 0.65 & 0.276121817 \\
\hline Thailand & 0.74 & 0.86 & 0.80 & 0.70 & 0.76 & 0.159453856 \\
\hline
\end{tabular}

* The advanced and emerging economies are listed in the first column separated by a horizontal line. The upper 20 countries are the advanced economies considered in our study and the lower 8 countries are the emerging countries. Fundamental credit scores and market credit scores are given in the second and the third column. The Fitch's scores are the score obtained from Fitch's rating using the mapping given in Table 14 Weights are the credibility weights ( $\omega$ in Equation $\sqrt{4}$ ) computed by $\frac{2}{2+\frac{\sigma^{2}}{\tau^{2}}}$. The $\delta-$ score listed in the last column are the weighted averaged scores of fundamental and market credit score using the credibility weights.

Table 13: Fundamental and Market implied Ratings Scores 


\begin{tabular}{|c|c|c|c|c|c|c|c|c|}
\hline 1 & $\mathrm{AAA}$ & Stable & 0.67 & $\mathrm{BBB}+$ & Watch Positive & 0.34 & $\mathrm{~B}+$ & Negative \\
\hline 0.99 & AAA & Negative & 0.66 & $\mathrm{BBB}+$ & Positive & 0.33 & $\mathrm{~B}+$ & Watch Negative \\
\hline 0.98 & AAA & Watch Negative & 0.65 & $\mathrm{BBB}+$ & Stable & 0.32 & B & Watch Positive \\
\hline 0.97 & $\mathrm{AA}+$ & Watch Positive & 0.64 & $\mathrm{BBB}+$ & Negative & 0.31 & B & Positive \\
\hline 0.96 & $\mathrm{AA}+$ & Positive & 0.63 & $\mathrm{BBB}+$ & Watch Negative & 0.3 & B & Stable \\
\hline 0.95 & $\mathrm{AA}+$ & Stable & 0.62 & $\mathrm{BBB}$ & Watch Positive & 0.29 & B & Negative \\
\hline 0.94 & $\mathrm{AA}+$ & Negative & 0.61 & $\mathrm{BBB}$ & Positive & 0.28 & B & Watch Negative \\
\hline 0.93 & $\mathrm{AA}+$ & Watch Negative & 0.6 & $\mathrm{BBB}$ & Stable & 0.27 & B- & Watch Positive \\
\hline 0.92 & $\mathrm{AA}$ & Watch Positive & 0.59 & $\mathrm{BBB}$ & Negative & 0.26 & B- & Positive \\
\hline 0.91 & $\mathrm{AA}$ & Positive & 0.58 & $\mathrm{BBB}$ & Watch Negative & 0.25 & B- & Stable \\
\hline 0.9 & AA & Stable & 0.57 & BBB- & Watch Positive & 0.24 & B- & Negative \\
\hline 0.89 & AA & Negative & 0.56 & BBB- & Positive & 0.23 & B- & Watch Negative \\
\hline 0.88 & $\mathrm{AA}$ & Watch Negative & 0.55 & BBB- & Stable & 0.22 & $\mathrm{CCC}$ & Watch Positive \\
\hline 0.87 & AA- & Watch Positive & 0.54 & BBB- & Negative & 0.21 & $\mathrm{CCC}$ & Positive \\
\hline 0.86 & AA- & Positive & 0.53 & BBB- & Watch Negative & 0.2 & $\mathrm{CCC}$ & Stable \\
\hline 0.85 & AA- & Stable & 0.52 & $\mathrm{BB}+$ & Watch Positive & 0.19 & $\mathrm{CCC}$ & Negative \\
\hline 0.84 & AA- & Negative & 0.51 & $\mathrm{BB}+$ & Positive & 0.18 & $\mathrm{CCC}$ & Watch Negative \\
\hline 0.83 & AA- & Watch Negative & 0.5 & $\mathrm{BB}+$ & Stable & 0.17 & $\mathrm{CC}$ & Watch Positive \\
\hline 0.82 & $\mathrm{~A}+$ & Watch Positive & 0.49 & $\mathrm{BB}+$ & Negative & 0.16 & $\mathrm{CC}$ & Positive \\
\hline 0.81 & $\mathrm{~A}+$ & Positive & 0.48 & $\mathrm{BB}+$ & Watch Negative & 0.15 & $\mathrm{CC}$ & Stable \\
\hline 0.8 & $\mathrm{~A}+$ & Stable & 0.47 & $\mathrm{BB}$ & Watch Positive & 0.14 & $\mathrm{CC}$ & Negative \\
\hline 0.79 & $\mathrm{~A}+$ & Negative & 0.46 & $\mathrm{BB}$ & Positive & 0.13 & $\mathrm{CC}$ & Watch Negative \\
\hline 0.78 & $\mathrm{~A}+$ & Watch Negative & 0.45 & $\mathrm{BB}$ & Stable & 0.12 & $\mathrm{C}$ & Watch Positive \\
\hline 0.77 & $\mathrm{~A}$ & Watch Positive & 0.44 & $\mathrm{BB}$ & Negative & 0.11 & $\mathrm{C}$ & Positive \\
\hline 0.76 & $\mathrm{~A}$ & Positive & 0.43 & $\mathrm{BB}$ & Watch Negative & 0.1 & $\mathrm{C}$ & Stable \\
\hline 0.75 & $\mathrm{~A}$ & Stable & 0.42 & BB- & Watch Positive & 0.09 & $\mathrm{C}$ & Negative \\
\hline 0.74 & $\mathrm{~A}$ & Negative & 0.41 & BB- & Positive & 0.08 & $\mathrm{C}$ & Watch Negative \\
\hline 0.73 & $\mathrm{~A}$ & Watch Negative & 0.4 & BB- & Stable & 0.07 & $\mathrm{D}$ & Watch Positive \\
\hline 0.72 & A- & Watch Positive & 0.39 & BB- & Negative & 0.06 & $\mathrm{D}$ & Positive \\
\hline 0.71 & A- & Positive & 0.38 & BB- & Watch Negative & 0.05 & $\mathrm{D}$ & Stable \\
\hline 0.7 & A- & Stable & 0.37 & $\mathrm{~B}+$ & Watch Positive & 0.04 & $\mathrm{D}$ & Negative \\
\hline 0.69 & A- & Negative & 0.36 & $\mathrm{~B}+$ & Positive & 0.03 & $\mathrm{D}$ & Watch Negative \\
\hline 0.68 & A- & Watch Negative & 0.35 & $\mathrm{~B}+$ & Stable & & & \\
\hline
\end{tabular}

* This table shows the mapping from numerical credit score between 0 to 1 to the standard alphabets ratings from $\mathrm{D}$ watch negative to AAA stable.

Table 14: Ratings and Corresponding Scores 

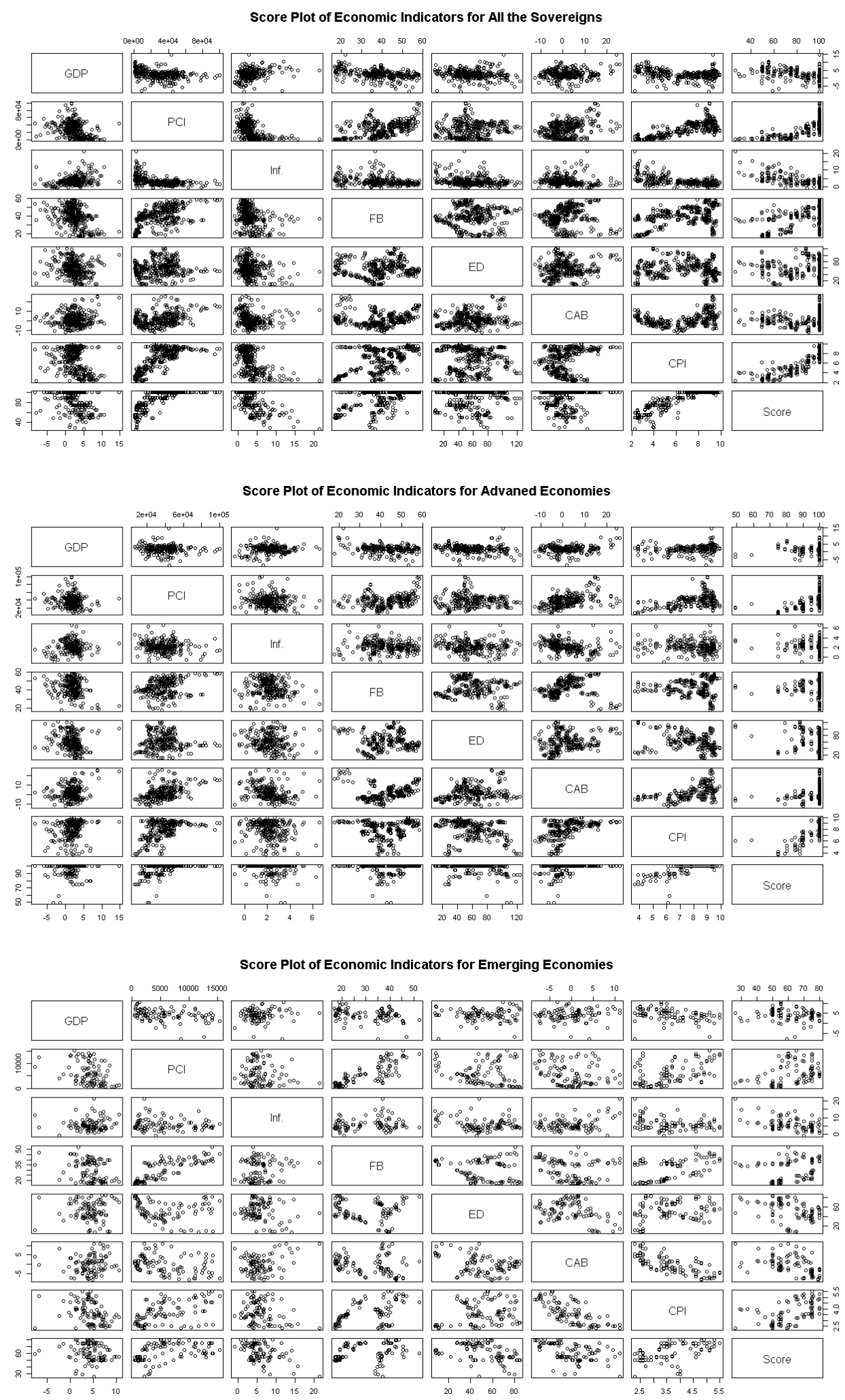

* This figure presents the economic indicators exhibited in Table 1 except for the two dummy variable (economic development and default history) and the rating scores. The upper, medium and lower plots are respectively, the score plots of the variables of all the sovereigns, the advanced economies and the emerging economies.

Figure 1: Score Plot of Economic Indicators 

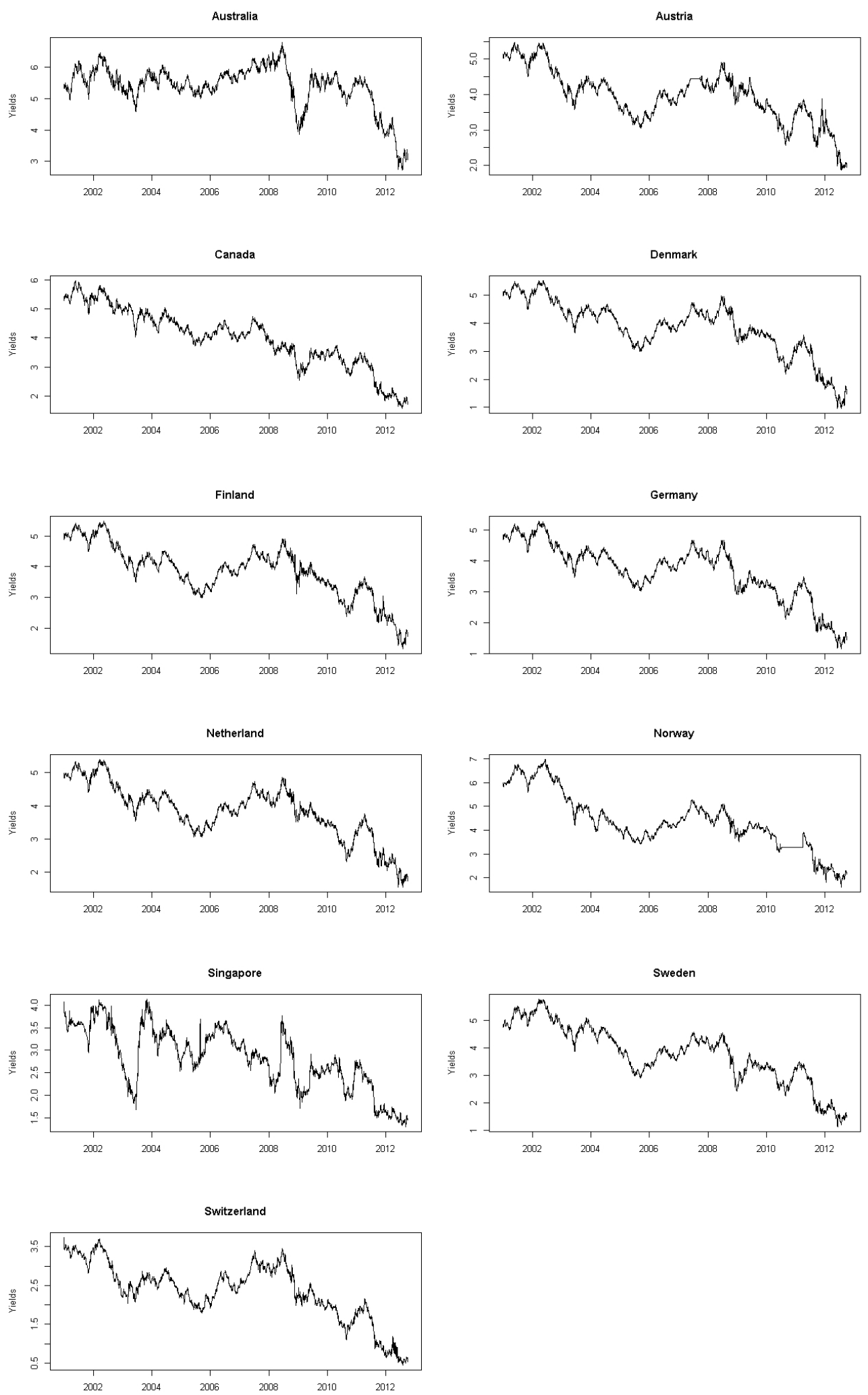

*These eleven countries: Australia, Austria, Canada, Denmark, Finland, Germany, Netherland, Norway, Singapore, Sweden and Switzerland, are the countries which has had a AAA/Stable rating during the whole period from 2001 to 2012.

Figure 2: Government Benchmarks 10 Year Bond Yields of the Advanced AAA/Stable Rated Countries 

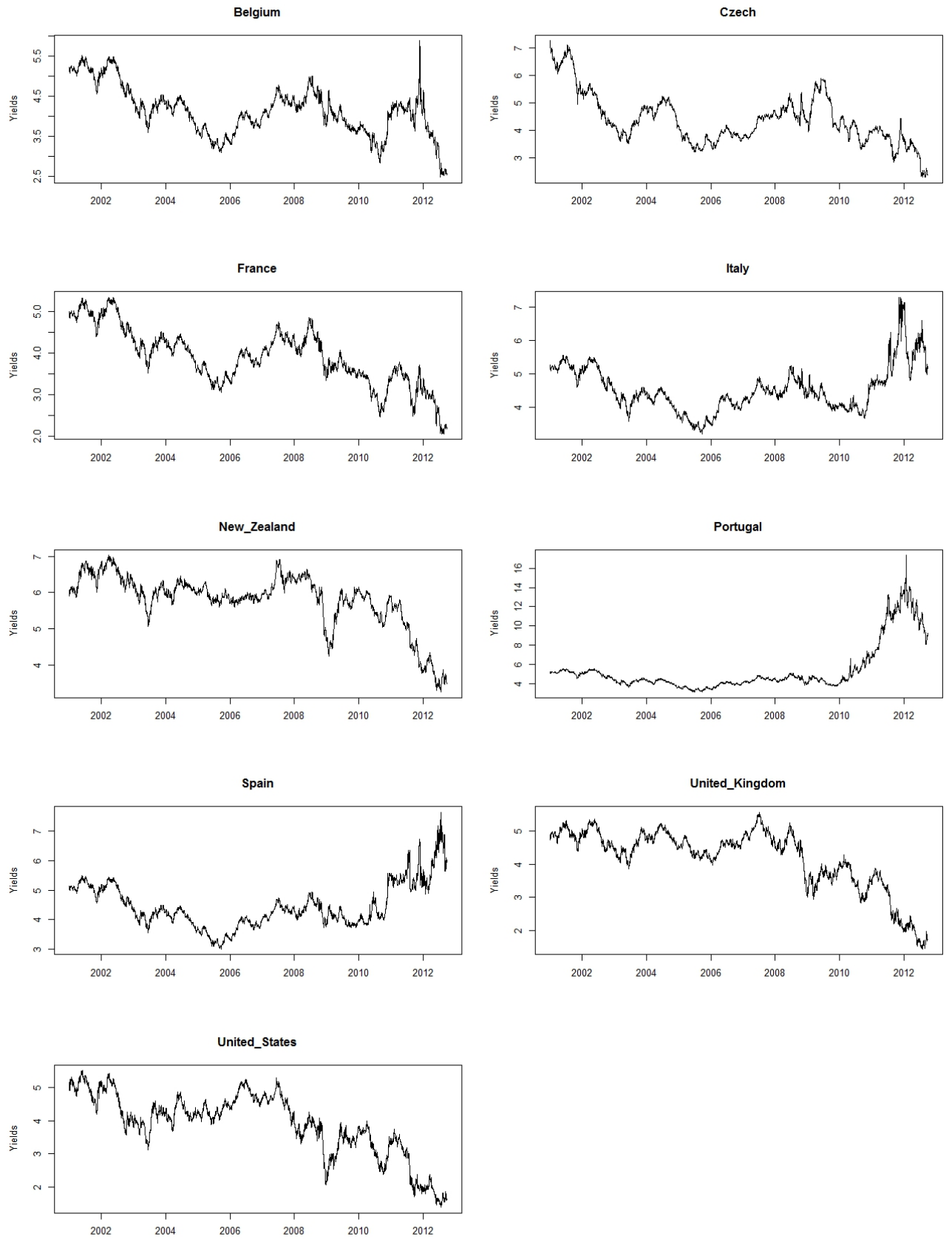

*These nine countries: Belgium, Czech, France, Italy, New Zealand, Portugal, Spain, United Kingdom and United States are the countries in the advanced economies group which have been downgraded during the sample period.

Figure 3: Government Benchmarks 10 Year Bond Yields of the Downgraded Advanced Countries 

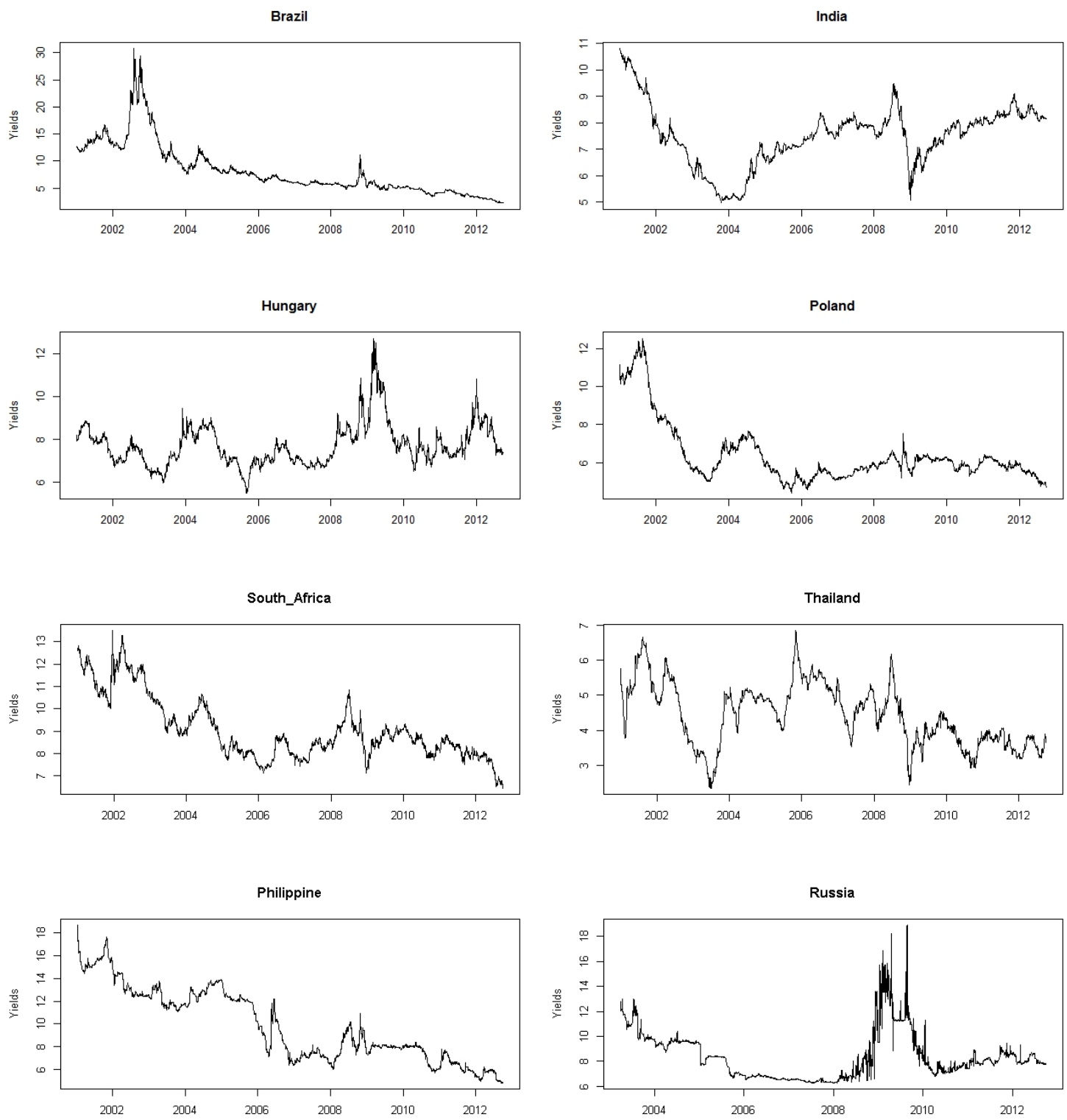

*These eight countries are the emerging economies in the sample. The data of Brazil, India, Hungary, Poland, South Africa and Thailand start from 01/01/2001 to 30/09/2012. The data of Philippine start from 16/01/2001 and end at 30/09/2012. The data of Russia start at $21 / 03 / 2003$ and end at $30 / 09 / 2012$.

Figure 4: Government Benchmarks 10 Year Bond Yields of the Emerging Countries 

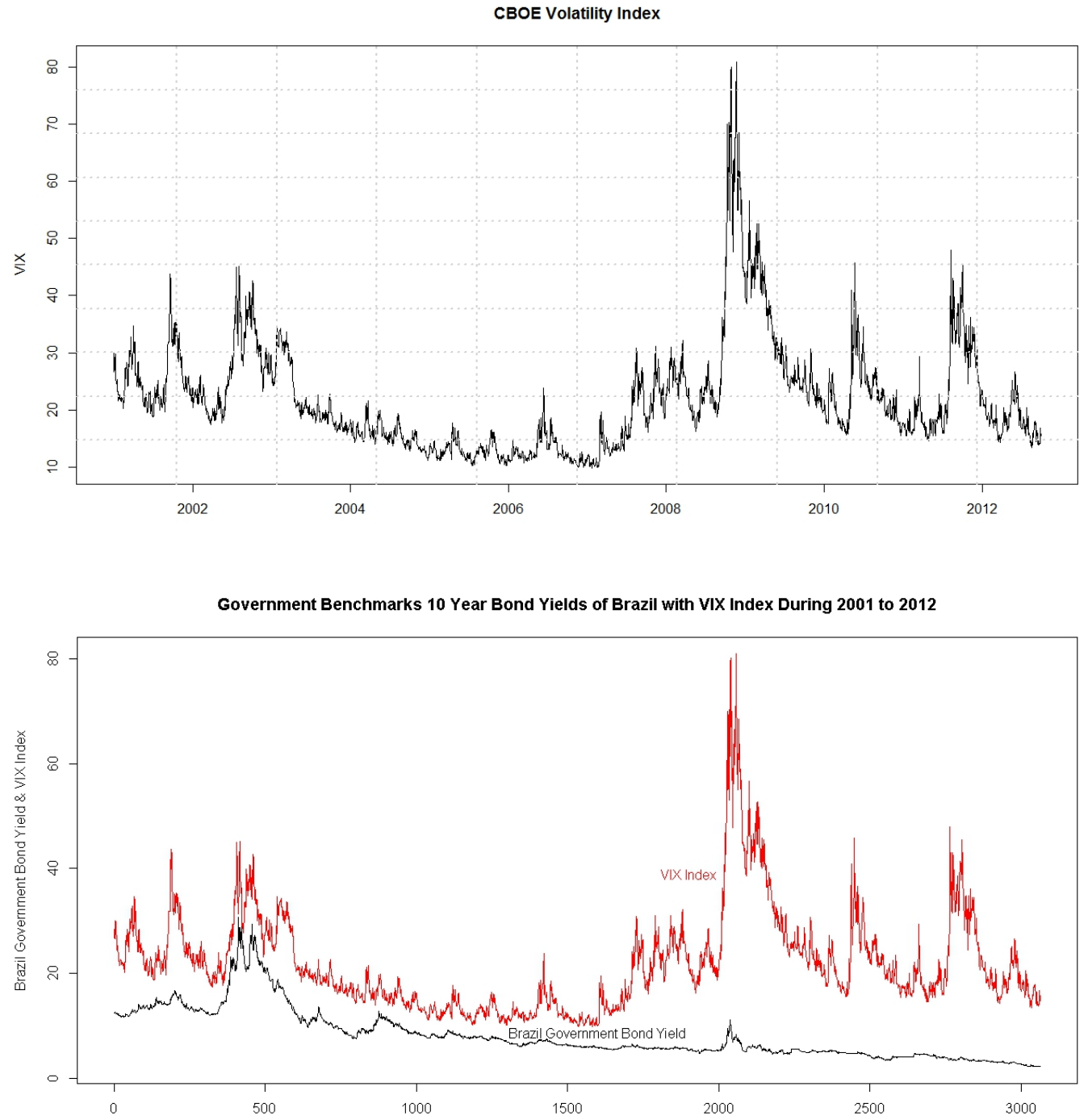

The upper graph illustrates the movement of the VIX index during the sample period. The lower graph plots the times series of Brazil bond yields and VIX.

Figure 5: 10 Year Government Bond Yields of Brazil with rating announcements and VIX Index 